WORKING PAPER NO. 5

Oct 1994

\title{
A Review of Tropical Forestry and Agroforestry Problem Areas and Policy Research Needs and the Planned Response of the CGIAR System
}

\author{
J. Spears, P. Oram, N. Byron, S. Scherr and A.M. Izac
}

\begin{abstract}
Summary
Recognizing that policy research would become a high priority for CGIAR related forestry and agroforestry research, it was decided in 1990 to sponsor a series of forestry and agroforestiy policy workshops involving national forest policy and research institution leaders, representatives of local and international NGOs and donor agencies. The objective was to obtain a better understanding of the main problem areas that could benefit from a CGIAR strategic research input.

The key issues that emerged from the five workshops are summarized in this report. Tropical forestry and agroforestry problem areas and policy research needs are reviewed in Part I and Annex 3 of the report. Based on the discussion in Part I, Part II introduces the policy research programs of the CGIAR Centres, focusing on CIFOR, ICRAF and IFPRI, and presents the research priority setting and planned responses of these CGIAR Centres to each of the identified five problem areas.

The program of intercentre collaboration and possible research activities outlined in the report is based on unconstrained resources which would ensure that CIFOR, ICRAF and IFPRI are allocated the resources requested in their Medium Term Plans. Thus, the Workshop series and this final report should not only be viewed as a research agenda which will trigger immediate responses but also as a useful mechanism for formulating the CGIAR Centres' long-term policy research direction and research needs to be addressed by national research institutions.
\end{abstract}

In Collaboration with
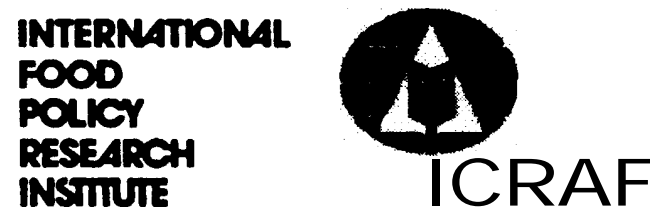

CENTER FOR INTERNATIONAL FORESTRY RESEARCH Jalan Gunung Batu 5 Bogor 16001 Indonesia tel.: +62(25 1) 34-3652 fax: +62(25 1) 32-6433 email: cifor@cgnet.com 


\section{The CGIAR System}

The Consultative Group on International Agricultural Research (CGIAR) is an informal association of 41 public and private sector donors that supports a network of sixteen international agricultural research centers, CIFOR being the newest of these centers. The Group was established in 1971. The CGIAR centers are part of a global agricultural research system which endeavor to apply international scientific capacity to solution of the problems of the world's disadvantaged people.

\section{CIFOR}

CIFOR was established under the CGIAR system in response to global concerns about the social, environmental and economic consequences of loss and degradation of forests. It operates through a series of highly decentralized partnerships with key institutions and/or individuals throughout the developing and industrialized worlds. The nature and duration of these partnerships are determined by the specific research problems being addressed. This research agenda is under constant review and is subject to change as the partners recognize new opportunities and problems. 


\section{CONTENTS}

Executive Summary

Part I: A Review of Tropical Forestry and Agroforestry Problem Areas and 10 Research Needs

$\begin{array}{ll}\text { Introduction } & 10\end{array}$

The Policy Workshops $\quad 11$

The Global Workshop $\quad 11$

The Asia Workshop 12

The Africa Workshop 14

The Latin American Workshop 18

Discussion of Predominant Common Themes 20

Forestry and Agroforestry Policy Research Methodology and Institutional Capacity 21

Part II: The Forestry and Agroforestry Policy Research Programs of the CGIAR Centers 22

(a) Criteria for the Selection of Problem Areas and Research Needs that would be most 22 appropriate for CGIAR Support

(b) Emphasis on Forestry and Agroforestry Policy Research in the Medium Term Plans 23 of CIFOR, ICRAF and IFPRI

(i) Center for International Forestry Research (CIFOR) 23

(ii) International Centre for Research in Agroforestry (ICRAF) 23

(iii) International Food Policy Research Institute (IFPRI) 23

(c) The CGIAR' s Planned Response to the Recommendations of the Regional 24

Forest Policy Workshops

Problem Area I: Policies to Contain inappropriate Tropical Deforestation 25

Problem Area 2: Valuation of Forest and Tree Benefits 26

Problem Area 3: Local Participation $\quad 27$

Problem Area 4: The Role of Trees and Forests in Rural Welfare 28

Problem Area 5: Policy Options for Improving the Efficiency of Forest Industries 29 and Productivity of Forest Management

(d) Alternative Modes of Intercentre Collaboration 29

(i) Containment of Deforestation in the Brazilian Amazon: the Global 30

Alternatives to Slash and Burn Project

(ii) Testing of Alternative Institutional approaches to Forest Management 32

(e) Phasing of the CGIAR Centres' Forestry and Agroforestry Policy Research Activities 34

Annex 1: $\quad$ Priorities for Forestry and Agroforestry Policy Research 35

Annex 2: $\quad$ Synthesis of Main Problem Areas and Research Needs 38 


\title{
A Review of Tropical Forestry and Agroforestry Problem Areas and Policy Research Needs and the Planned Response of the CGIAR System
}

\author{
J. Spears ${ }^{1}$, P. Oram², N. Byron ${ }^{3}$, S. Scherr ${ }^{2}$ and A.M. Izac ${ }^{4}$ \\ Background
}

The idea of holding an international workshop on priorities for forestry/agroforestry policy research stemmed from discussions among a number of concerned scientists, some of whom (Hans Gregersen, Peter Oram, John Spears) had been involved in TAC, CGIAR, IUFRO, and other discussions on international research needs for the forestry sector, the potential role of the CGIAR and what IFPRI's contribution might be within this larger framework. IUFRO and USAID offered to fund such a workshop, and it was agreed to hold it in Washington with IFPRI as the operational focus and host.

A key recommendation of this workshop was to follow up with similar workshops in each of the major geographical regions where tropical forestry is important, and IFPRI was asked to pursue this. The aim was to delineate more specifically the problems and priority areas for research, and to identify those researchable issues common to several countries, the results of which would have broad applicability; as well as where international action might be needed when problems transcended national boundaries or presented difficult methodological challenges.

IFPRI agreed to take on this task, and Peter Oram, who had the primary responsibility for organizing the international workshop, was designated by IFPRI as task manager. John Spears and Hans Gregersen played an important advisory role, and John participated in the Asian and African workshops. Sara Scherr, who had been present at the international workshop and who joined IFPRI in 1991, participated in the Asian, African, and Latin American Workshops; Manuel Paveri of FAO also participated in the Asian, African, and Latin American workshops and provided a valuable link with FAO's Forest Policy Program. Marc de Montalambert, Director, Forest Policy and Planning Division in FAO, also attended the International and Asian workshops, and FAO was the lead agency managing the joint FAO/IFPRI Asian workshop in Bangkok. Ronnie de Camino was the main partner in the Latin American initiative. Peter Oram played the leading role in raising funds, organising all of the workshops jointly with IFPRI's partners in Asia (FAO), Africa (ICRAF), and Latin America (IICA), running the three regional meetings, and writing the reports. He, John Spears, Sara Scherr and AnnMarie Izac participated in the Bogor workshop and contributed to the draft report. Neil Byron convened and organised this last meeting and also attended the Washington and Asian workshops.

\section{Executive Summary}

The key issues that emerged from regional workshops are summarised in this report. It was recognized from the outset that the range of problem areas and policy research topics likely to emerge from this exercise would far exceed the capacity of the CGIAR system to respond. Nevertheless, it was considered useful in formulating research agendas, to carry out a broadly based review of this subject working in close collaboration with IUFRO and FAO. PART I of this report provides regional and global overviews of key problem areas, common themes and research topics, based on interaction with a wide range of national and international policy leaders, scientists, FAO, NGOs and donor agency representatives. PART II of the report summarises the planned responses of the CGIAR Centres.

\section{Discussion of Predominant Common Themes}

An analysis of the main problem areas and high priority research needs emerging from the

1. Formerly with CGIAR Secretariat in Washington, D.C.

2. International Food Policy Research Institute, 1200 Seventeenth Street N.W. Washington, D.C. 20036-3006, USA.

3. Center for International Forestry Research, P.O.Box. 6596, JKPWB, Jakarta 10065, Indonesia.

4. International Centre for Research in Agroforestry, United Nations Avenue, PO Box. 30677, Nairobi, Kenya. 
workshops suggests that five broad problem areas appear to be of common concern to policy leaders in the Asia, Africa and Latin American regions. They are:

- The impact of tropical deforestation on human welfare as well as on both local and global environments; the need for improved understanding of the main underlying causes of deforestation; and policy reforms that could most effectively contribute to its containment.

- The uses of the forests, and their economic and environmental values and benefits are poorly understood and frequently underestimated. This has had a negative effect on national government, aid agency and private sector resource allocations and investment priorities relating to conservation and management of forest resources.

- Past policies that have placed strong emphasis on centralised decision making, ownership and control of forest resources, have deterred involvement of local people in their management. These policies have been partly responsible for past failures to protect forests and for the extensive degradation of forest lands in many parts of the tropics.

As natural forests throughout the developing world have been depleted and degraded, local populations have increasingly turned to remnant patches of open woodlands, forest fallows and other agroforestry farming systems for supplying their essential forest product needs and for inputs required to maintain agricultural productivity.

This evolution of supply sources of tree products from natural forest/gathered or harvested products to products that are obtained from domesticated on-farm or community wood-lot trees or plantations, has led to many new policy challenges. Because the interactions between crops, livestock and trees are not well understood, government agroforestry incentive and extension policies are frequently ineffective and wasteful of scarce resources.

- The countries of South East Asia, West Africa and Latin America with abundant tropical timber have in the past, or stil do to a significant degree, depend on timber harvesting and forest product exports for generating revenues that support economic development.

A combination of political pressures to accelerate harvesting, corruption, the weakness of government forest administrations, inappropriate concession license allocation and timber taxation systems, and the negative impact of macroeconomi $\mathrm{c}$ trade, exchange rate and structural adjustment policies, have led to wasteful use of resources and failure to capture economic rental values.

The introduction o $f$ accelerated industrialisation policies has, in some situations, exacerbated poor forest management and been costly in terms of job creation, loss of potential revenues, lack of preservation of the environmental benefits of forests and loss of agricultural sustainability.

Environmental concerns to protect rainforests for global benefit and to protect the way of life of forest dwelling communities have led to pressures on southern governments to restrict timber exports, to the introduction of tropical timber import restrictions and to other interventions. The impact of these interventions on local people, on economic growth prospects and on the possibilities for improved conservation and management of forest resources is poorly understood.

Annex 2 of this report summarises high priority research needs for addressing the five problem areas outlined above, based on the conclusions and recommendations of this series of Policy Workshops.

\section{Planned Forestry and Agroforestry Policy Research Programs of the CGIAR Centres}

In responding to the above problems, the CGIAR Centres are giving high priority to research topics that fit with the CGIAR's Mission Statement which requires the Centres to focus on:

"International research and related activities in partnership with national research institutions that will contribute to sustainable improvements in the productivity of agriculture, forestry and 
fisheries in developing countries in ways that enhance nutrition and well being, especially of low income people."

Working within this framework, the CGIAR system is well placed to make a significant contribution to tackling many of the key aspects of the five problem areas summarised above.

\section{Center for International Forestry Research (CIFOR)}

In broad terms, CIFOR will concentrate its main policy research effort on tackling underlying causes of' tropical deforestation; on improved understanding of policies and incentives to ensure increased productivity and sustainable management of natural forests and reforestation of degraded lands; on researching systems aimed at valuation and more equitable distribution of the benefits of forest goods and services (with a special focus on non-timber forest products); on alternative institutional options for involving local people in forest management and on policies that will help to improve the quantification, preservation and monitoring of the environmental benefits of tropical forests (including the biodiversity of tropical forest ecosystems and their carbon sequestration potential). CIFOR's Policy Research Program will embrace five main areas of activity:

- Policies and Incentives for Sustainable Forest Management.

- Valuation and Equity of Benefits and Costs of Forest Goods and Services.

- Adoption of Policy Change.

- Employment and Income from Forests and Woodlands.

- Future Supplies and Demands for Forest Goods and Services.

\section{International Centre for Research in Agroforestry (ICRAF)}

ICRAF's policy related research will continue the strong emphasis that ICRAF has given over the last 15 years to farm level research aimed at improved understanding of household level and community perceptions of the value and uses of on-farm trees and remnant woodlands, particularly from the perspective of the role that they play in contributing to agricultural sustainability and food security, and to the farmers' welfare.

ICRAF is also spearheading the Global "Alternatives to Slash and Burn" Project through which a consortium of national and international research institutions is implementing a research program aimed at tackling one of the main contributors to tropical deforestation, i.e. shifting cultivation in situations of increasing population pressure, shortening fallow periods, declining crop yields and ecological degradation. ICRAF's Medium Term Plan defines three main areas of agroforestry policy research. They are:

- Agroecosystem characterisation of priority environments and land use systems to identify constraints and opportunities for agroforestry research and to delineate extrapolation domaines.

- Development of an understanding of how selected policies constrain or support the adoption of agroforestry technologies and design of adoption mechanisms for policy implementation.

- Impact assessment, the objectives of which are to measure the ecological, economic and social impacts of key agroforestry technologies on agricultural sustainability, rural poverty, farmers' welfare, environmental preservation and climate change.

\section{International Food Policy Research Institute (IFPRI)}

IFPRI's main contribution will be implemented by IFPRI's recently established Environment and Production Technology Division, particularly through two projects that will focus on "Forest Margins" and "Fragile Lands". These projects will incorporate case studies of institutional arrangements for promoting sustainable resource use; marketing studies focussing particularly on forest and non-forest tree products; methodologies for assessing the interrelationships among soil degradation and farm level resource management decisions (especially forest conversion); participatory community monitoring systems to assess the effect of policies on natural resource management (including forests and trees). Also IFPRI will continue to work on how macroeconomic and structural adjustment policies affect agricultural productivity, equity, 
trade and the environment (areas in which IFPRI's past research experience could be of considerable relevance to the forestry sector).

IFPRI will also play a role in the socioeconomic policy research dimensions of the Global "Alternatives to Slash and Burn" Project. Five main areas of agroforestry and forestry policy related research to be undertaken by IFPRI include:

- Arresting deforestation and resource degradation in the forest margins of the humid tropics.

- Sustainable development in fragile forest lands.

- Property rights and communal action for forest resource management.

- Tree product markets.

- Macroeconomic policy, trade and the environment.

\section{The CGIAR'S Planned Response to the Recommendations of the Regional Forest Policy Workshops}

In response to the recommendations of the Regional Forest Policy Workshops, CIFOR hosted a Forest Policy' Workshop in Bogor, Indonesia in February 1994. Representatives from four Centres - CIFOR, ICRAF, IFPRI and CIAT - participated in that Workshop. The two main objectives of this Workshop were:

- Selection of problem areas and research needs that tit well with the various CGIAR Centre mandates, in execution of which the CGIAR would have some comparative advantage and which, in terms of CGIAR goals are deserving of highest priority.

- Possible modes of intercentre collaboration that would exploit the complementary strengths of different Centres.

The main problem areas and research needs discussed were those identified by the Regional Workshop participants as summarised above and in Annex 2 of this report. In addition to the two main objectives of the meeting, the Workshop also briefly discussed:

- Preliminary identification of geographic situations where CGIAR field research sites might be located.
- The importance of closest possible collaboration with NARs. These were defined in a broad context to include a range of different local institutions such as national forestry research institutions, universities, specialised policy research institutes, NGOs and government policy researchers and decision makers located in various different ministries.

- The role of the CGIAR Centres in Policy Research Training.

These three latter points (and particularly the role of the NARs) will be a major focus of the follow up discussions that the three individual Centres are now in the process of implementing within the various geographic regions in which they will be concentrating their policy related research activities. Because these regional interactions with NARs are still ongoing, and because further time is needed to develop more specific proposals on the CGIAR Centres' possible contribution to policy research training, this report only summarises the conclusions and recommendations of the Bogor Workshop emerging from discussions of the two main objectives of the meeting. Table 1 at the end of this Executive Summary lists the research topics emerging from the Bogor Workshop discussions that were regarded as being of high priority for CGIAR support and that fit well with the research agendas already defined in the Medium Term Plans of CIFOR, ICRAF and IFPRI, which cover the period 1994-1998. These include 28 of the 40 different research topics identified by the Regional Workshops. Table 1 also indicates the research areas of particular interest to CIFOR, ICRAF and IFPRI.

More detailed discussion of the precise areas of research that will be pursued by these three Centres is the main subject of Part II of this report. In discussing this question the Workshop was particularly concerned that the complementary areas of interest and research expertise which they possess are used to the best advantage.

In addition to the planned forestry and agroforestry policy related research activities of these three Centres, the CGIAR designated "ecoregional" Centres such as Centro International de Agricultura Tropical (CIAT) in Latin and Central America, The International Institute of Tropical Agriculture (IITA) in West Africa, The International Crops Research 
Institute for the Semi Arid Tropics (ICRISAT) in the arid zones of South Asia and Africa, The International Rice Research Institute (IRRI) working in the humid tropics of South East Asia, and the International Centre for Agricultural Research in Dry Areas (ICARDA) in the Middle East will also be playing a significant role in natural resource related research in the ecoregional zones that fall within their geographic mandates.

Of these other ecoregional Centres, only CIAT was represented at this Workshop. The contribution of the CGIAR ecoregional Centres to forestry and agroforestry research will also be a focus of the follow up discussions and research activities that CIFOR, ICRAF and IFPRI have already initiated, or which they now plan to undertake within the regions. For that reason no attempt has been made in this report to cover the likely research agendas of these Centres.

\section{Modes of Intercentre Collaboration and Complementary Research}

A major thrust of the Workshop discussions focussed on the interdependency and interlinkages between many of the 28 research topics that appear to be most appropriate for CGIAR support, and on how the Centres could most effectively collaborate so as to address these research topics in an integrated way. It is the CGIAR's intention to combine the biological and socioeconomic scientific expertise of various CGIAR Centres to take into account their comparative strengths and complementary research mandates.

To tackle major globally important environmental problems (such as the negative impact on human welfare and the global environment of slash and burn agriculture in tropical forests), some of the five problem areas identified in Part I of this report might most effectively be addressed by establishing an ecoregional network of CGIAR Centres, national research institutions and specialised research agencies working collaboratively in preselected sites in each of the three major geographic regions (Asia, Latin America and Africa).

There would be advantages in appointing a "Convening Centre" the function of which would be to orchestrate and ensure the creation of effective coordination mechanisms for such global research programs. This is the model that has been followed in setting up the Global "Alternatives to Slash and Burn" (ASB) Project for which ICRAF is acting as the Convening Centre.

Options were explored for achieving cost savings in situations where all three Centres have an interest in pursuing a topic from their respective perspectives (such as the influence of various land tenure systems on the interest of local communities and small scale farmers to conserve and manage forest and tree resources). In such situations it would clearly be possible for the three Centres to combine in engaging the services of a single social scientist who, working collaboratively with an appropriate national research institution, would be able to implement the necessary research on a site of mutual interest to all three Centers. Other major problem areas and strategic research needs of common interest to the three regions might more effectively be tackled by an informal consortium of CGIAR Centres, national institutions and specialised agencies independently working on various interrelated aspects of the same problem over a range of mutually agreed sites. For such networks there may be no need for a "Convening Centre" provided that clearly defined arrangements are put in place for ensuring common methodological approaches, for periodic interaction on progress and assessment of emerging results. To illustrate how these alternative approaches might work in practice in relation to CGIAR implemented agroforestry and forestry research programs, the Bogor Workshop discussed two specific problem areas. These were:

- Containment of deforestation in the Rondonia/Acre region of the Brazilian Amazon (which is one of eight benchmark sites selected for implementation of the Global ASB Project).

- Testing of various alternative institutional approaches to forest and agroforestry management over a range of Asian, African and Latin American regional sites. Special emphasis will be given to testing the validity of a hypothesis that in many tropical forest and agroforestry situations, forest resources are likely to be conserved and more productively managed by local communities, "user groups" or other locally 
devised institutional approaches, rather than by centralised public forest agencies.

Discussion of the former topic was based on the premise that as the ASB Project proceeds the research agenda in its Phase II will be broadened to focus on the sort of macroeconomic and other policy dimensions listed under Problem 1 in Table 1. There are highly complementary areas of research in the ASB Project that could benefit from a strong input from all three Centres in addition to the expertise that is already being brought to bear on the slash and burn problem by social science researchers from CIAT, IITA and IRRI. Further details of how such complementarity will work in practice, in implementation of Phase II of the ASB Project are discussed in this report.

An alternative mode of operation was explored for tackling issues such as that of "Alternative Institutional Approaches to Forest and Agroforestry Management". The Bogor Workshop gave very high priority to the desirability of a more concerted research effort in this area. Out of the range of possible research needs listed in Annex 2 that emerged from the Regional Workshops, it concluded that the six topics listed under points 3.1-3.6 of Table 1 are those that should be strongly supported by the CGIAR.

In contrast to the mode of intercentre collaboration described above for the ASB Project (where several CGIAR Centres and national institutions are all working within the same ecoregional site), the Workshop concluded that research on local participation issues such as those identified in Table 1 might be more effectively implemented through a more diffuse networking approach.

Under this alternative mode of operation there may be no need for a "Convening Centre" provided that at the outset, there has been a collective effort firstly, to establish common research methodologies; secondly, to coordinate selection of collaborating NARs and specialised research institutions; thirdly, to arrange regular interaction in reviewing emerging results and progress (much of which can now be assured at relatively low cost by making effective use of electronic networking); fourthly, to possess clear mutual understanding from the outset on the likely outputs and potentially different target beneficiaries of such research. Part II of this report discusses how the above mode of operation is already being applied in practice to the ongoing research programs of CIFOR, ICRAF and IFPRI.

\section{Forestry and Agroforestry Policy Research Methodology and Institutional Capacity}

In all live Workshops concerns were expressed about weaknesses in current forest and agroforestry policy research methodology and the weakness of national institutional capacity for policy analysis. A particularly critical constraint is the lack of solid empirical data on which to base meaningful policy analysis. An associated issue is the need for more effective ways of ensuring that the recommendations arising out of policy research are more widely adopted. A range of options was discussed for overcoming these bottlenecks.(for detailed discussion see section on the Africa Region Workshop Report). Some of the most pressing needs identified in this area included for example:

- A more interdisciplinary approach to field farm and forest surveys to develop quantitative measures of key variables on tree production, income, use, etc. and to provide benchmarks for research analysis.

- Historical reconstruction of land use change using archival research, oral history, historical studies in geography, anthropology and farm management, plus review of local legal records to identify changes in ownership and land use conflicts.

- Rigorously designed qualitative studies to understand patterns of consumption, tree use preferences, and control and management.

- Exploring options for permanent monitoring systems to parallel those already widely used for crops and livestock. Examples cited included national agroforestry surveys under implementation in Burundi, analysis of trees in land use through use of remote sensing techniques, tree product market surveys and long term monitoring of agroforestry farming system yields.

- Better understanding of the political and institutional constraints to adoption of policy reforms. This reflects the reality that 
despite the considerable investment that has been directed to policy research in the past and the prodigious lists of recommendations that have been generated for policy reform and institutional change, the political unacceptability of such recommendations has frequently precluded their adoption. Better mechanisms are needed for interaction with political leaders and national government agencies responsible for policy formulation.

It was recognized that institutional approaches to research require closer integration among forestry research institutions and specialised, socioeconomic, anthropological, agriculture and energy research agencies.

\section{Phasing of the CGIAR Centres' Forestry and Agroforestry Policy Research Activities}

The Bogor Workshop discussions were primarily concerned with the substance of a desirable CGIAR research agenda and with the issue of how to ensure effective intercentre collaboration. The program of possible research activities outlined above is based on unconstrained resources which would ensure that the three main Centres under discussion are allocated the resources requested in their Medium Term Plans. The current financial climate in which the CGIAR is operating may require hard decisions to be made about prioritisation and phasing of their forestry and agroforestry policy research activities.

Table 1.

\begin{tabular}{|c|c|c|c|c|}
\hline \multicolumn{5}{|c|}{ FOREST POLICY RESEARCH SYNTHESIS WORKSHOP } \\
\hline & PROBLEM AREA & CIFOR & ICRAF & IFPRI \\
\hline \multicolumn{5}{|c|}{$\begin{array}{l}\text { PROBLEM } 1 \text { : POLICIES TO CONTAIN INAPPROPRIATE TROPICAL } \\
\text { DEFORESTATION }\end{array}$} \\
\hline 1.1 & $\begin{array}{l}\text { The influence of macroeconomic and sectoral } \\
\text { policies (including structural adjustments) on } \\
\text { regional development patterns, on economic growth } \\
\text { prospects, trade, and on incentives for deforestation } \\
\text { and tree/forest management. }\end{array}$ & $\mathrm{X}$ & $\mathrm{X}$ & $\mathrm{X}$ \\
\hline 1.2 & $\begin{array}{l}\text { Analysis of factors that influence population } \\
\text { migration at source and monitoring of the } \\
\text { dynamics of population migration patterns (e.g. } \\
\text { land tenure). }\end{array}$ & $\mathrm{X}$ & & $\mathrm{X}$ \\
\hline 1.3 & $\begin{array}{l}\text { The influence of agricultural policies on } \\
\text { colonization, agricultural and forest conversion, } \\
\text { including the impact of slash and burn farming on } \\
\text { deforestation. }\end{array}$ & $\mathrm{x}$ & $\mathrm{x}$ & $\mathrm{X}$ \\
\hline 1.4 & $\begin{array}{l}\text { Improved understanding of the potential of forest } \\
\text { buffer zone policies to relieve pressure on } \\
\text { biologically unique forest reserves and protected } \\
\text { areas and of land tenure and incentive policies that } \\
\text { are likely to be most effective in involving local } \\
\text { people in their protection and management. }\end{array}$ & $\mathrm{X}$ & $\mathrm{X}$ & $\mathrm{X}$ \\
\hline 1.5 & $\begin{array}{l}\text { Pol:icies for major highway and rail construction } \\
\text { programs that divert infrastructure projects away } \\
\text { from forest inhabited by indigenous forest dwellers } \\
\text { and from high priority biodiversity reserves. }\end{array}$ & & & \\
\hline 1.6 & $\begin{array}{l}\text { Intersectoral planning processes as they relate to } \\
\text { forest resources. }\end{array}$ & & & $\mathrm{x}$ \\
\hline
\end{tabular}




\begin{tabular}{|l|l|c|c|c|}
\hline \multicolumn{2}{|c|}{ PROBLEM AREA } & CIFOR & ICRAF & IFPRI \\
\hline 2.1 & $\begin{array}{l}\text { Improved methods for evaluating the costs and } \\
\text { benefits of tree/forest goods and services, including } \\
\text { human and environmental effects of deforestation, } \\
\text { the impact of commercialization of forest products } \\
\text { on different socioeconomic and gender groups, } \\
\text { externality benefits of forests and trees. }\end{array}$ & $\mathrm{X}$ & $\mathrm{X}$ & $\mathrm{X}$ \\
\hline 2.2 & $\begin{array}{l}\text { Testing standardized methodologies for the } \\
\text { valuation of non-traditional forest products and } \\
\text { monitoring the dynamics of demand, supply and } \\
\text { prospects for domestication and commercialization. }\end{array}$ & $\mathrm{X}$ & $\mathrm{X}$ & $\mathrm{X}$ \\
\hline 2.3 & $\begin{array}{l}\text { Evaluation of tree product markets. } \\
2.4\end{array}$ & $\begin{array}{l}\text { Obtain data on the potential effects of low impact } \\
\text { harvesting technologies and more careful forest } \\
\text { management on carbon emissions,carbon } \\
\text { sequestration value of forests, evaluate possible } \\
\text { mechanisms for NorthSouth concessional transfers } \\
\text { to provide incentive for setting aside and or } \\
\text { establishment of forests reserves in the interest of } \\
\text { protecting environment. }\end{array}$ & $\mathrm{X}$ & $\mathrm{X}$ \\
\hline
\end{tabular}

\begin{tabular}{|l|l|c|c|c|}
\hline PROBLEM 3: LOCAL PARTICIPATION & $\mathrm{X}$ & $\mathrm{X}$ \\
\hline 3.1 & $\begin{array}{l}\text { Improved understanding of factors influencing } \\
\text { household level decisions to conserve, manage } \\
\text { forests, trees and of policy incentives to encourage } \\
\text { their involvement. }\end{array}$ & $\mathrm{X}$ & $\mathrm{X}$ \\
\hline 3.2 & $\begin{array}{l}\text { How various forms of land tenure and tree } \\
\text { ownership policies can influence the prospects for } \\
\text { improved welfare of forest dwelling people and more } \\
\text { effective conservation and management of forest } \\
\text { resources and influence the adoption of agroforestry. }\end{array}$ & $\mathrm{X}$ & $\mathrm{X}$ \\
\hline 3.3 & $\begin{array}{l}\text { Analysis of the legal and institutional constraints to } \\
\text { local participation in forest conservation and } \\
\text { management and adoption of agroforestry systems } \\
\text { and policies to address them. }\end{array}$ & $\mathrm{X}$ & $\mathrm{X}$ & $\mathrm{X}$ \\
\hline 3.4 & $\begin{array}{l}\text { Standardized methodologies for evaluating and } \\
\text { monitoring alternative institutional approaches to } \\
\text { forest management, in terms of their impact on } \\
\text { human welfare, the productivity of forest resources } \\
\text { and on environmental protection. }\end{array}$ & $\mathrm{X}$ & $\mathrm{X}$ \\
\hline 3.5 & $\begin{array}{l}\text { Improved understanding of indigenous forest } \\
\text { dwelling people's rights of use and access, and } \\
\text { policies to preserve those rights. }\end{array}$ & $\mathrm{X}$ & $\mathrm{X}$ \\
\hline 3.6 & $\begin{array}{l}\text { Policy options for reform of public sector forest } \\
\text { agencies (including analysis of past experiences). }\end{array}$ & & $\mathrm{X}$ \\
\hline
\end{tabular}




\begin{tabular}{|c|c|c|c|c|}
\hline \multicolumn{2}{|r|}{ PROBLEM AREA } & CIFOR & ICRAF & IFPRI \\
\hline \multicolumn{5}{|c|}{ 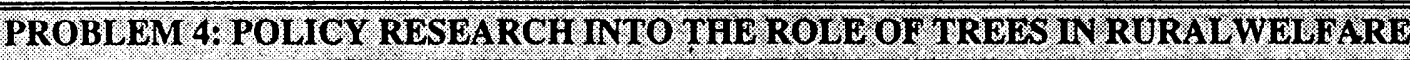 } \\
\hline 4.1 & $\begin{array}{l}\text { Understand and quantify the contribution of on farm } \\
\text { trees and remnant woodlands and forests to } \\
\text { nutrition, food security, agricultural sustainability, } \\
\text { rural income generation, reduction of risk in } \\
\text { farming systems and protection of soil and water } \\
\text { resources. }\end{array}$ & & $\mathrm{X}$ & $\mathrm{X}$ \\
\hline 4.2 & $\begin{array}{l}\text { Policy research into traditional agroforestry farming } \\
\text { systems and into policies that would stimulate their } \\
\text { wider adoption and improved productivity. }\end{array}$ & & $\mathrm{X}$ & \\
\hline 4.3 & $\begin{array}{l}\text { How to get household agroforestry needs } \\
\text { (distinguished by gender, etc.) incorporated into } \\
\text { public agency support policies. }\end{array}$ & - & $X$ & $\mathrm{X}$ \\
\hline 4.4 & $\begin{array}{l}\text { Evaluation of policy options for degraded land } \\
\text { reclamation. }\end{array}$ & $\mathrm{X}$ & $\mathrm{X}$ & $\mathrm{X}$ \\
\hline 4.5 & $\begin{array}{l}\text { Agroeconomic zoning including use of satellite } \\
\text { monitoring and GIS technology for policy planning } \\
\text { (e.g. definition of areas scheduled for reclamation by } \\
\text { afforestation). }\end{array}$ & $\mathrm{X}$ & $X$ & \\
\hline
\end{tabular}

\begin{tabular}{|c|c|c|c|c|}
\hline \multicolumn{5}{|c|}{ 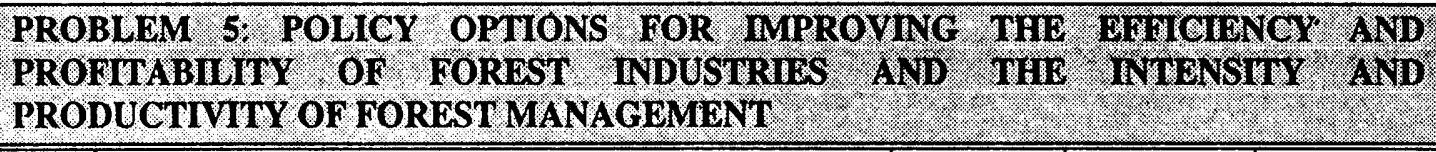 } \\
\hline 5.1 & $\begin{array}{l}\text { Viability and constraints to improved efficiency of } \\
\text { small scale wood using industries and into their } \\
\text { potential contribution to rural welfare and economic } \\
\text { growth. }\end{array}$ & $X$ & & \\
\hline 5.2 & $\begin{array}{l}\text { Effect of macroeconomic and trade policies on the } \\
\text { timber trade (e.g. structural adjustments, exchange } \\
\text { rates, tariffs).[cross referenced with } 1.1 \text { ] }\end{array}$ & $X$ & & $X$ \\
\hline 5.3 & $\begin{array}{l}\text { Improved quantification of the costs and benefits of } \\
\text { accelerated industrialization policies, including } \\
\text { increased domestic processing, versus log exports. }\end{array}$ & $X$ & & \\
\hline 5.4 & $\begin{array}{l}\text { Impact of government timber concession license and } \\
\text { taxation policies on the prospects for improved } \\
\text { rental capture and more intensive forest } \\
\text { management. }\end{array}$ & $X$ & & \\
\hline 5.5 & $\begin{array}{l}\text { Improved understanding of the likely impact on the } \\
\text { livelihood of local people, on economic growth and } \\
\text { on forest conservation and management of } \\
\text { environmentally driven proposals for restrictions on } \\
\text { tropical logging and the timber trade (eco-labelling). }\end{array}$ & $X$ & & \\
\hline
\end{tabular}




\section{Part I: A Review of Tropical Forestry and Agroforestry Problem Areas and Policy Research Needs}

\section{Introduction}

During the latter half of the 1980s the CGIAR, interacting with both national and international scientific leaders, environmental groups and donor representatives, undertook an intensive review of its mandate with the objective of strengthening its strategic research relating to the conservation and sustainable management of natural resources. As one outcome of that debate, a decision was taken to incorporate forestry research into the CGIAR system. After reviewing several alternative institutional options it was decided to bring two new research centres into the system:

- CIFOR ( Center for International Forestry Research, in Bogor, Indonesia), and

- ICRAF ( International Centre for Research in Agroforestry, in Nairobi, Kenya)

CIFOR's mission statement is:

"Promoting the sustained well being of people in developing countries particulurly in the tropics through collaborative strategic and applied research on forestry systems and by promoting the adoption of improved technologies and management practices."

ICRAF has as its mission statement:

"Increasing the social, economic and nutritional well being of the people of developing countries and, through the use of research and relhted activities, to integrate woody perennials in farming and related land use systems in order to increase productivity, profitability, sustainability, diversity of output and the conservation of natural resources.

In addition to the forestry and agroforestry related research of these two Centres, it was also agreed that several other International Agricultural Research Centres (IARCs) within the CGIAR system and particularly IFPRI (The International Food Policy Research Institute), CIAT (Centro International de Agricultural Tropical), and IPGRI (The International Plant
Genetic Resources Institute) would also give some attention to forestry and/or agroforestry research problems (the latter mainly related to the biological and institutional aspects of germplasm and biodiversity conservation). CIFOR which came into existence in 1993 and ICRAF which had been in existence as a nonCGIAR Research Council since 1978, both give strong emphasis to policy research in their Medium Term Plans (MTPs), which cover the period 1994-98.

In the case of CIFOR, there is clear recognition in its MTP that much inappropriate land use and tropical deforestation can be attributed to inappropriate institutional arrangements and government economic and sectoral policies. In allocating priorities between various programs, CIFOR gives policy research a very high profile, in recognition that investment in policy research leading to policy and institutional reforms, will yield a high payoff in terms of prospects for improved well being of forest dwelling people and better conservation and management of tropical forest resources.

ICRAF, from the beginning, gave special attention to interactive socioeconomic diagnostic research at the farm household level. The intention was to ensure that its research programs were based on farmers' perceptions of the usefulness of trees in agroforestry farming systems and their traditional tree management practices.

This emphasis has carried through to ICRAF's current MTP which includes a major objective of developing an understanding of how selected policies constrain or support the adoption of agroforestry technologies. It also recognizes that strategic research on agroforestry can contribute to resolution of globally important environmental issues such as the negative impact of slash and burn agriculture on rural poverty and forest degradation.

Whilst the primary concern of the CGIAR is strategic research of global relevance, very strong emphasis is given to the importance of close collaboration with national agriculture and forestry research institutions and with NGOs, universities and specialised policy research institutions in the implementation of the IARCs' policy research agendas.

The CGIAR Centres are also heavily involved in programs aimed at strengthening 
the research capability of national research institutions. About 20 per cent of past CGIAR expenditures have been devoted to research, training and dissemination of research information.

CIFOR, which is a "centre without walls" will implement a very substantial part of its policy research agenda through collaborative and contractual arrangements with both national and international institutions. Prior to the incorporation of ICRAF and CIFOR into the CGIAR system, IFPRI carried the main responsibility in the CGIAR system for agriculture related policy research. It had conducted a number of policy research studies relevant to the forestry sector. IFPRI therefore took a lead role in initiating this work. CIFOR undertook the responsibility for consolidation of the Workshop output and organisation of an intercentre dialogue on how the CGIAR could respond to priority research needs most effectively.

\section{The Policy Workshops}

\section{(a) The Global Workshop}

The Global Workshop which initiated this series, brought together forty participants from countries. The objectives were to sound out expert opinion on the potential of policy research to contribute to resolution of constraints to sustainable forest conservation and management, giving high priority to the role that forests and trees play in meeting human needs, contributing to agricultural sustainability, protecting the environment and to economic growth. The initial discussions focussed on defining information requirements for different stages of the policy research process (see Table 2).

The Global Workshop discussions recognized that many forestry and agroforestry policy issues are quite site and situation specific and that much current research is in the form of case studies that do not lend themselves to extrapolation. A critical challenge is to design studies using standardised or comparable methods and carefully selected cases to provide rigorous empirical evidence that can be extrapolated to address broader policy concerns.

\section{Common Policy Themes and Research Areas}

Most of the issues suggested by the Workshop participants fell into six cross cutting categories:

- Macroeconomic policies that influence forest land use and distribution of forest benefits.

- Land and tree tenure issues.

- Ways of optimizing land use and rural welfare.

- The effects of institutional reform.

- Institutional support services and infrastructure.

- Markets, subsidies and incentives.

Table 2.

\begin{tabular}{|l|l|}
\hline $\begin{array}{l}\text { Questions at Each Stage Leading to Policy } \\
\text { Changes }\end{array}$ & Information Requirements \\
\hline $\begin{array}{l}\text { 1. What is the existing situation and what } \\
\text { changes are desirable to achieve particular } \\
\text { development objectives related to sustainable } \\
\text { development and the environment? }\end{array}$ & $\begin{array}{l}\text { Background information } \\
\text { Needs and problem assessment } \\
\text { Market information } \\
\text { Technical information (biophysical, social and } \\
\text { economic) }\end{array}$ \\
\hline $\begin{array}{l}\text { 2. What inputs into the local, regional, or } \\
\text { national economy have to change to achieve } \\
\text { these development objectives? }\end{array}$ & $\begin{array}{l}\text { Research on the means for changing forestry } \\
\text { and agroforestry activities, reflecting social and } \\
\text { economic constraints and opportunities. }\end{array}$ \\
\hline $\begin{array}{l}\text { 3. What policies have been effective in achieving } \\
\text { development objectives? What policy changes } \\
\text { are required to alter the existing situation in a } \\
\text { way that meets development objectives? }\end{array}$ & $\begin{array}{l}\text { Policy Research } \\
\text { Studies of effects and opportunities for } \\
\text { achieving development objectives through } \\
\text { policy change related to incentives and } \\
\text { regulations. }\end{array}$ \\
\hline
\end{tabular}


Within the above framework, the Global Workshop examined how the above categorisation of research themes might be applied in practice to some of the more obvious problem areas that have been widely recognized both at the national and international levels as being in urgent need of attention. These five problem areas were:

- The relationship between population distribution and growth, deforestation and sustainable land use in the humid tropics. Special attention would be given to policies that would help to address the problem of shifting cultivation and forest migrant pressures on forest resources.

- Policy options that could have a beneficial impact on reclamation and improved utilisation of degraded forests in dryland regions.

Policies that could influence the possibilities for sustainable land use, containment of erosion and regulation of stream flow in upland watersheds.

- The role of trees in income and welfare security addressing social and economic issues relating to the use of trees and tree products in farming systems by communities and small scale wood using enterprises.

- Intersectoral issues affecting the forestry sector, such as those influencing agricultural expansion, structural adjustment programs, road developments and energy sector policies and strategies.

The outcome of this analysis is summarised in Annex 1. The purpose of the Global Workshop was to provide a starting point for this policy research review and to stimulate further discussion of key issues. The Regional Workshops which followed were intended to sound out the perceptions of local people, national policy leaders, NGOs and others on key problems and researchable issues as seen from their perspective. The following sections of this report summarise the key topics and recommendations that emerged during the regional meetings that were held in Asia, Africa and Latin America.

\section{(b) The Asia Workshop}

The participants in the Asia region Workshop were representative of several quite different agroecological zones and countries with substantially different fores resource endowments. The first broad grouping included the countries of the South East Asia region such as Indonesia, Malaysia, Myanmar, and Papua New Guinea, which contain very substantial natural forests that are a major source of export earnings and local employment. They include the biologically diverse dipterocarp rain forests that have been the target of much international attention and environmental concern over the last decade.

A second grouping included the countries of the South Asia region such as India, Pakistan, Nepal, Bangladesh and Sri Lanka which contain substantial areas of dry or semi arid zone woodlands, extensive mountain uplands, degraded lands and areas of very high population density in which the natural forests have been largely depleted but in which open woodlands, agroforestry and homestead tree plantings play a major role in meeting human needs.

Problems and research needs of the islands of the South Pacific region were represented by the participation of Fiji. Problems of temperate forest region emerged from input of the representatives of China, Japan, New Zealand and Australia.

The representatives of both Thailand and Philippines highlighted the perspective of countries that have, in the past, been major exporters of forest products, but in which the natural forests have now been severely depleted to the point that forest policies are strongly driven by the need to preserve the remaining forests and to accelerate reforestation in order to meet rapidly rising domestic needs for forest products.

Despite the disparity between the forestry situations of these various groupings, several common problems that are of regional concern quite quickly emerged. Those that featured most prominently in the discussions were: 
(i) Problems of increasing pressures on forest resources, the negative effects of deforestation and the need for improved understanding of policies that can help to contain forest encroachment.

Prominent among the possible research topics suggested that could help to address this problem were

- Macroeconomic policies that may have a negative impact on forests. These include indirect pressures from structural adjustment and other macroeconomic interventions such as export and exchange rate policies, environmental related pressures exerted through trade relations, timber boycotts, debt for nature exchanges, the conditional lending policies of aid agencies and the policies of NGOs.

- Intersectoral effects of national government policies on both forestry and agroforestry.

- Improved understanding of policies that could help to reduce shifting cultivation, including those likely to influence planned and spontaneous migration, such as skewed land tenure and the easier access to cheap forest land provided by highways and logging roads.

Notwithstanding the overriding concerns of national forest policy leaders to conserve what remains of the natural forests of the Asia region, it was acknowledged that some continued deforestation is inevitable (particularly where forests situated on relatively flat land overlie soils with reasonable agricultural potential and where there is still a possibility to increase agricultural production by transfer of forest land to agriculture).

In situations where further transfer of forest land to agriculture is being contemplated, a priority will be to identify and exclude from the forest excision process, areas of forest that are particularly important sources of biodiverse germplasm of plant and animal species, which protect critical upland watersheds. Research into the socioeconomic and soil capability aspects of alternative forest land uses (including protection of the interests of forest dwelling communities) should precede such land transfers wherever possible.

Policy research needs in this latter area include improved understanding of the economic trade-off between forest and alternative forms of land use and of the incentive, land tenure and other policies that will help to ensure an orderly transfer from forestry to agriculture or other uses.

(ii) The need to broaden the technological basis for sustainable management of natural forests by greater emphasis on the harvesting and management of non-traditional forest products.

High priority research topics in this area included:

- Improved knowledge on the uses and values of non-traditional products.

- Marketing prospects and pricing policies that encourage their increased but sustainable productivity.

- Issues of the protection of local people's rights relating to ownership of germplasm, forest products or processing methods, and of policies that can preserve those rights.

(iii) Institutional concerns relating to possibilities for decentralisation of management responsibility for forest resources and involvement of local communities, user groups and private enterprises of various kinds in forest management.

Discussions of this topic covered a wide range of options and ongoing experiences ranging from the recent joint management schemes that are being tested in India to small user group experiences in Nepal, the transition from centrally planned resource management in China to management by local communities and individuals, and transfer of management responsibility to large scale private sector industrial enterprises as has occurred with the recent privatisation of plantation forests in New Zealand Priority research topics included:

- Policies that affect ownership and tenure rights to both forest lands and trees.

- The need for improved methodologies for assessing the equity, technical effectiveness and environmental impacts of transferring ownership of forest resources.

- Policy research directed at options for reform of traditional forest services to encourage improved integration and 
collaboration with other both public and private sector agencies including NGOs.

(iv) Policies affecting trees in land use outside forests including those that are likely to have a beneficial impact on accelerated adoption of improved agroforestry farming systems and reclamation of degraded lands.

As the natural forests of the Asia region are being depleted, many of the products they supplied such as fuelwood, fruits, tree fodder, building poles and timber are now being substituted by similar products harvested from remnant patches of open woodland, forest fallows, individual indigenous trees that have been protected in the course of conversion from forest to agriculture and especially by on-farm tree planting as an integral component of the agroforestry farming systems that are widely in evidence throughout the region. This significant change in the structure of forest products supply has led to many new policy challenges. There is also growing concern in the region about the extensive areas of former forest but now degraded imperata grasslands, saline soils and arid zone wastelands; and trees have a useful role to play in the reclamation of such lands. Key research topics to address these problems would include:

- Evaluation of economic returns to land and labor in agroforestry systems, including trees, crops, livestock, income generation and the potential of various components of these farming systems to contribute to family employment, nutrition and sustainable agricultural productivity compared to other alternative forms of land use.

- Tree product market research including the potential of forest products derived from agroforestry farming systems to substitute key subsistence products and farming input needs that were formerly derived from natural forests.

- Incentive measures to stimulate trees in land use or to remove disincentives (taxes on trees, or tree products, bans on tree cutting, etc.).

- Agroeconomic zoning research aimed at improved delineation of areas of degraded land where reforestation or afforestation are likely to be economically viable and socio economically acceptable.

(v) Industrialisation policies that are intended to stimulate improved harvesting and forest management, the creation of local employment and increased revenue generation.

These issues that were of primary interest to major timber producing countries such as Indonesia, Myanmar, Malaysia and Papua New Guinea led to identification of the following research needs:

- The influence of macroeconomic and structural adjustment policies on the productivity and viability of forest industries.

- Options for improved license and taxation systems for timber concessions.

- Improved understanding of the economic and technical impact of log export bans and accelerated domestic industrialisation policies.

- improved understanding of the policies that could foster the development of smaller scale rural wood-using enterprises and introduction of low impact harvesting technologies.

- Policy options for maximizing economic rental capture from harvesting of natural forests and improved mechanisms for ensuring equitable revenue sharing with local communities as well as adequate resource allocations and incentives to encourage more intensive and sustainable forest management.

- Improved understanding of the impact of environmentally driven trade embargoes such as timber boycotts on forest industrial development on both human welfare and the conservation and improved management of forest resources.

\section{(c) The Africa Workshop}

This Workshop was attended by 42 policy makers, senior staff of public and private forestry institutions, agroforestry specialists and NGOs. As in the Asia Workshop, the participants represented several quite different agro ecological, socio economic and forest 
resource endowment situations. Those African countries that still contain substantial areas of natural forest and which have either in the past or still do rely on trade of forest products as a potential source of revenue and employment, were represented by participants from Côte d'Ivoire, Cameroon, Nigeria and Zaire. The arid zone countries of the Sahel and West Africa region in which savanna woodlands have been heavily depleted by a combination of agricultural cropping, grazing and fuelwood harvesting pressures, were represented by Niger and Benin.

The countries of the East and Southern African region in which climatic and soil conditions are in many areas quite favorable for forest growth but in which agricultural population pressures have already caused natural forest depletion, or are likely to in the future, were strongly represented by participants from Kenya, Tanzania, Zimbabwe, Malawi, Lesotho, Botswana and South Africa. In some countries in this region there has been quite vigorous development in agroforestry farming systems.

Fast growing industrial plantations of mainly exotic species such as pines, eucalypts and cypress play a key role in several of these countries in meeting domestic timber needs and, in some countries, paper and paperboard needs. Several of the African region participants had specialised expertise in this area. The interests of conservation and NGO groups were represented by UNEP and CARE. Several leading socioeconomic policy researchers from African universities and agricultural and land tenure policy research specialists from overseas institutes also participated. Based on considerable earlier interaction with policy researchers and NGOs from the region and consultation with African policy leaders attending the 1992 FAO Africa Regional Forestry Commission, it had been agreed in advance to focus discussion around five main themes. These were:

- Population distribution and growth; related changes in land use and their impact on deforestation in the humid tropical forest zone of the West Africa region. Special emphasis was given to identification of policies that could help ease the transition from slash and burn to more sedentary farming systems.
- Identification of policy measures that could help shift the emphasis from traditional forest products to multipurpose end use forest management (giving special reference to improved understanding of the consumption patterns, marketing prospects and sustainable management options for forest-based foods, fruits, fuelwood, fodder, mulch, medicinal and other products).

- Improved understanding of how modified government forest revenue and timber allocation policies influence sustainable forest management and of the scope for potentially beneficial policy changes.

- Improved understanding of the potential benefits and risks associated with devolution of responsibility for natural forest management from government control to management at the local level by communities, user groups, private individuals or commercial companies, and of the policies that could help encourage smooth shifts in tenure or ownership of forest resources.

- Research on the role of trees in rural income, subsistence and food and energy security with special emphasis on improved understanding of policies that can contribute to more accurate targeting of incentive mechanisms for encouraging use of trees in farm and community forestry.

Four working groups reviewed these and related issues, and the Regional Report on this Workshop sets out the detailed discussions and conclusions of those working groups. The initial working group discussions identified about 35 major problem areas. A preliminary list of about 120 research needs emerged. Considerable time was spent in synthesizing the most crucial cross cutting problem areas and research topics that seemed most relevant to addressing these problems. In summary the following four problem areas and related research priorities reflect the main conclusions and recommendations of the Africa Workshop:

\section{(i) Inadequate understanding of the uses and value of forests, open woodlands and trees.}

The historical preoccupation of most African Government Forest Departments with control, protection and management of "reserved" forests for preserving water catchment areas, 
wildlife reserves and with harvesting and management of forests for conventional forest products such as lumber, plywood and pulp and paper, is largely a heritage of colonial forest administrations.

Population pressures on many of these government controlled forest "reserves" were, in the early days of their creation, not perceived as a major problem. Little importance was attached to economic quantification of forest values. Primary management objectives in earlier times were strongly driven by the conviction that it was the responsibility of Government Forest Departments to protect and manage these forest reserves on behalf of the people and in the interest of future generations. Local people's rights and communal land ownership of forest lands were frequently ignored in the process of forest reservation.

Population pressure and deforestation have led to the recognition that national forest policies need to place stronger emphasis on incentives for the development of improved agroforestry farming systems, on the management of open savanna woodlands, fragmented patches of natural forest outside forest reserves and on improved management of forest fallows and shrubs (which in total account for more than 70 per cent of Africa' s wooded area). However so far, there has been inadequate attention on research into the uses and values of non-traditional forest products, the relevance of savanna woodland trees and forest fallows to sustainable agriculture or to improved understanding and quantification of the wider environmental benefits of forests. Within Africa the main ongoing research into improved understanding of forest values is being conducted by relatively few African universities, by overseas specialised policy research institutes and NGOs and in the case of research into agroforestry benefits, by ICRAF working mainly with local farmers and national agricultural and forest department researchers. The low level of resources devoted to this topic and lack of trained social scientists within Africa, are constraints to improving knowledge. Formulation of incentive policies for ensuring that the benefits of a wider range of forest products and environmental services are incorporated into national forest policies and development programs, requires that greater research be devoted to:
- Agroecological research aimed at clarifying the significantly different uses and values of forests in Africa's various ecozones (for example, research issues in the Sahel region are substantially different from those of the East and Central African highlands and from those of the humid tropical countries of the West Africa region).

- Understanding and quantifying the contribution of forests, open woodlands and trees to nutrition, food security, agricultural sustainability, rural income generation, reduction of risk in farming systems; to medicinal needs and other non-traditional forest product needs.

- Understanding the potential for domestication and/or cultivation of indigenous fruits, medicine and other nonwood products of value for local consumption or sale.

- Identifying policies to encourage protection of existing tree resources (standing trees, natural regeneration) including forest and land use regulations, market incentives, land and tree tenure and processing.

- Improved methodologies for assessing the wider 'environmental benefits of forestry, including preservation of biodiversity, climatic influences and for monitoring of forest land use change.

- In this context there is potential to make more effective use of satellite technology backed up by cheap and rapid ground appraisal and evaluation methods supported by GIS (Geographic Information Systems).

(ii) Legal, tenurial and institutional constraints to effective community and private sector participation in forest management.

Incentive policies and institutional reforms are needed that will enable farmers and local communities to play a more effective role in resource conservation and management of forest resources. For example, recent forestry sector studies carried out in Zimbabwe, analysed the uses and values of forest products harvested from savanna woodlands and the incentives, land tenure, legal and institutional reforms that could be helpful in securing the participation of village communities in common property forest management of the savanna woodlands located 
in the Communal Areas. Research needs identified by the Workshop in this area included:

- Identifying the factors affecting people' s decision to protect existing forest resources and to plant trees. Improving understanding of how local regulations or other policies with respect to land tenure, land reform, access to land, customary user rights and restrictions on harvesting or sale of tree products impact on local people's willingness to plant and care for trees.

- Assessment of the comparative advantage of different institutional arrangements for the management of forest lands, including experimental testing and monitoring of alternative tenurial and management options. The role of NGOs in assisting in the formulation and testing of pilot approaches was recognized as being of particular importance.

- Development of standardised methodologies for measuring the effectiveness of alternative institutional approaches in relation to their impact on human welfare, agricultural sustainability and the environment.

(iii) Containing population migration into natural forests and woodlands and the need for improved understanding of policies that could help to slow migratory pressures.

In the humid tropical forest zone of West Africa, this problem is perhaps most acute in Côte d' Ivoire where over the last 15 years, some 5 million hectares of forest land have been converted to agriculture. Much of this is slash and burn farming being carried out in situations of increasing population pressure, shortened fallow periods, declining soil fertility and crop yields.

In the East and Southern African regions, the already quite small remaining areas of natural forest which were originally set aside to protect watersheds and wildlife resources are being eroded in some areas by population pressure on the forest fringes and the acute need to increase food supplies.

The savanna woodlands of northern Nigeria, the countries of the Sahel region and of Tanzania, Zimbabwe and other countries, have in some areas been heavily depleted by a combination of annual burning (to stimulate regrowth of fodder grasses or as a step towards conversion to agriculture), and by concentrated fuelwood harvesting particularly for charcoal production in the vicinity of major townships, and by large scale mechanised farming schemes such as those introduced in Sudan. Priority research needs in this area include:

- Improved understanding of the underlying causes of population migration at source and of the dynamics of population migration patterns.

- Policies aimed at the protection of forest dwelling communities who depend to a high degree on forest products for their subsistence needs and welfare.

- Research into alternative farming systems to slash and burn and into policies that will speed their adoption.

- Research into off-farm employment opportunities including the potential of small scale forest-based enterprises and the role that harvesting and sustainable management of forest products in buffer zones can play in helping to relieve pressure on protected forest areas.

- Improved understanding of the economics and environmental implications of land use change. (This is a highly relevant issue in parts of the Central and Southern African region where substantial areas of open savanna woodland situated on relatively flat land overlie soils with reasonable agricultural potential). It also has implications for part of the West African humid tropical forest zone where further conversion of some forest land to perennial tree crops can arguably be defended provided that care is taken to channel such development away from unique biodiversity areas and to protect the interests of forest dwelling communities.

(iv) The influence of macroeconomic and national development policies on forests and on prospects for sustainable forest products trade.

Research needs to address this problem include:

- Identification of the impact of government financial, fiscal, regulatory, tenurial and other policies on people's incentive to adopt sustainable forest conservation and management practices. 
- The impact of structural adjustment policies on forests.

- The impact of trade restrictions, taxes, log export embargoes, import tariffs and exchange rate changes on forest management.

- The influence of government concession license arrangements and private sector industrial development policies on harvesting and management.

\section{(d) The Latin American Workshop}

The regional participants in this Workshop represented three distinctly different forestry situations. The countries of the Amazon Basin that contain about half of the world's remaining rainforest were represented by participants from Brazil and Venezuela. The countries of the Latin American "cone" region, in which temperate climatic conditions predominate, use plantation forests to meet their industrial needs. In the case of Chile, these sustain a very substantial export trade in forest products. These countries were represented by Chile and Uruguay. Their concerns differ substantially from those in most tropical developing countries.

The Central American and Caribbean countries contain substantial areas of logged over and, in parts, badly degraded forests interspersed with fairly densely populated farm lands in which there has been substantial agroforestry tree planting. These countries were represented by participants from Costa Rica, Mexico, Honduras, Guatemala, Santo Domingo and Jamaica.

Agronomic and technical forestry expertise was represented by participants from Brazil, Costa Rica and by several leading agricultural and forestry scientists from both national and international agencies. NGO and environmental concerns were raised by representatives from the Smithsonian Institution and also by several aid agency representatives who have been on the receiving end of both national and global environmental criticisms of national government and aid agency forest policies. CGIAR institutes were represented by participants from IFPRI, ICRAF and CIFOR.

The main problem areas that were raised by representatives of the Amazon Basin countries focussed on both national and international concerns about tropical deforestation and its negative effects on prospects for sustainable forest products trade and forest land use. The key environmental issues of international concern such as preservation of biodiversity, the implications of deforestation for global warming and preservation of the human rights of forest dwelling tribal communities, are frequently at variance with national government and local authority preoccupations with poverty alleviation, economic growth and mobilisation of government revenues.

The preoccupations of the temperate "cone" countries stemmed from their desire to consolidate, expand and improve the productivity of fast growing plantation forests and to improve the efficiency and market share of their large scale forest industries. Major concerns of the Central American and Caribbean countries included policy options that would stimulate regeneration and improvement of secondary forests, incentives for greater involvement of local communities in forest management and the need to broaden the emphasis of forest management to give more attention to non-traditional forest products. Very similar concerns were raised to those that had surfaced in the three earlier workshops about the need to improve the understanding of policies and incentives that would lead to better targeting of agroforestry incentive policies and accelerated adoption of more promising agroforestry technologies. With this background the main problem areas of common interestwere:

\section{(i) How both national and international macroeconomic and environmental policies influence the possibilities for forest conservation, the welfare of forest dwelling people, forest products marketing and trade, and prospects for sustainable management of forest resources}

Because of the currently poor understanding of such relationships, high priority was given to the need for intensified research into:

- Marketing and export promotion policies that will make it possible for the countries of the region with surplus forest resources to meet domestic demands and to consolidate and expand their market share of international forest products trade. 
- The impact of structural adjustment, exchange rate, taxation, pricing and subsidy policies on forest industrial development, on forest management and on people's welfare.

- How the policies of other sectors and agencies responsible for formulation of transportation, agricultural colonisation, industrial and mining sector policies and subsidised private sector investment in such projects may negatively impact on forest resources and the livelihood of forest people.

- How to mobilise concessional funding for conservation of forest resources in situations where countries of the region are being urged to forego the potential benefits from forest harvesting in the interest of protecting biodiversity and the carbon sequestration potential of tropical forests for global benefit.

(ii) Improved understanding of the factors influencing population migration at source and of policies that could help to deter further migration into forests.

Key research needs identified include:

- The impact of skewed land distribution and potential of land reform to relieve population migration pressures.

- Better understanding of population dynamics and of the likely future trends in rural to urban population ratios.

- Possibilities for influencing highway and railway construction policies so as to avoid opening of unique forest ecosystems and tribal lands.

- Elimination of government supported agricultural subsidy policies that encourage speculation in forest land.

- Policies that will help to intensify agricultural productivity and encourage the development of stabilised communities away from forest areas.

(iii) The problem of undervaluation of forest resources.

Very similar concerns to those that had arisen in earlier Workshops were expressed, namely the desirability of intensified research on:
- Improved knowledge of the uses and value of non-timber forest products and of possibilities for their domestication and marketing.

- Improved quantification of the potential of smaller scale forest-based rural enterprises to contribute to rural income generation, economic growth and improved human welfare.

- Improved quantification of the environmental externality benefits of forests and factoring of the costs of forest depletion into national accounting systems.

(iv) Policy options that would help to ensure greater participation of local communities, small farmers and private sector industrial enterprises in sustainable management of forest resources.

NGO-supported experimental approaches for involving local communities in forest management have been attempted in countries such as Peru, Mexico and Costa Rica. Extractive Reserves have been set aside in Brazil, but prospects for their economic viability and sustainable management remain unclear. Fiscal incentives have been widely used in countries such as Chile and Brazil to induce private farmer and industrial company investment in plantation forestry. Despite the significant impact of these incentives in stimulating very large scale afforestation, past policy research has questioned the design of some of those programs. In particular, there was discussions whether enough attention was given at the outset to economic zoning of situations where such subsidies would have to lead to economically viablk forest industrial development. Research priorities included:

- Standardised methodologies for assessing the socioeconomic acceptability, technical performance and environmental sustainability of differing institutional approaches.

- Improved understanding of the cost effectiveness and justification for fiscal incentives and the need for agroeconomic zoning studies that can provide a basis for defining areas where such afforestation incentives are likely to be both economically justified and effective. 
- Improved understanding of the relative roles of the public and private sectors, and of institutional policy reforms that would result in more effective collaboration involving both local people and NGOs in policy dialogue.

(v) The need for improved understanding of policy options that would help to ensure more effective targeting of agroforestry interventions, of household level perceptions of the usefulness and improved management options for on-farm tree resources and degraded forest lands.

These issues are central preoccupations of several Central American and Caribbean countries. Technological and socioeconomic research carried out by CATIE in collaboration with national forestry and agricultural research institutions in the region have already made a significant contribution to improved understanding of the issues. Research needs included:

- Improved methodologies for monitoring the comparative impact of alternative agroforestry and more conventional farming systems on agricultural productivity and farm incomes.

- The relevance of different forms of land tenure and tree ownership to people's willingness to protect and manage on-farm trees.

- Gender issues as these affect household level decisions about forest and tree management.

- Improved understanding of the need and economic justification for fiscal incentive and other forms of subsidy that are aimed at accelerated adoption of tree planting and better tree management.

- Market research and processing opportunities for farm-derived forest products and of definition of policies that will enhance marketing and processing prospects.

\section{Discussion of Predominant Common Themes}

To summarise, the analysis of the main problems emerging from the series of
Workshops suggests that the following five broad problem areas appear to be of common concern in the Asia, Africa and Latin American regions:

- The impact of tropical deforestation on human welfare and on both local and global environments, and the need for improved understanding of the main underlying causes of deforestation, and policy reforms that could most effectively contribute to containment of further deforestation.

- The uses of the forests, their economic and environmental values and benefits are poorly understood and frequently underestimated. This has had a negative effect on national government, aid agency and private sector resource allocations and investment priorities relating to conservation and management of forest resources.

Past policies that have placed strong emphasis on centralised decision making, ownership and control of forest resources, have deterred involvement of local people in their management. These policies have been partly responsible for past failures to protect forests and for the extensive degradation of forests in many parts of the tropics. As natural forests throughout the developing world are being depleted and degraded, local populations have increasingly turned to remnant patches of open woodlands, forest fallows and other agroforestry farming systems for supplying their essential forest product needs and for inputs required to maintain agricultural productivity. This evolution of supply sources of tree products from natural forest/gathered or harvested products to products that are obtained from domesticated on-farm or community wood-lots or plantations, has led to many new policy challenges. However, government forest policies in many countries have failed to provide adequate policy incentives and support services to ensure either that remnant woodlands are well managed, or to enable local people to capitalise on the potential of agroforestry farming systems to supply essential human and livestock needs, and to contribute to increased agricultural productivity. Because the interactions between crops, livestock and trees are not well understood, government agroforestry incentive and extension policies are 
sometimes ineffective and wasteful of scarce resources.

- The countries of South East Asia, West Africa and Latin America with abundant tropical timber have in the past, or to a significant degree still do, depend on timber harvesting and forest product exports for generating revenues that support economic development.

A combination of political pressures to accelerate harvesting, corruption, the weakness of government forest administrations, inappropriate concession license allocation and timber taxation systems, and the negative impact of macroeconomic trade, exchange rate and structural adjustment policies, have led to wasteful use of resources and failure to capture economic rental values. The introduction of accelerated industrialisation policies has in some situations exacerbated poor forest management and has been costly in terms of job creation, loss of potential revenues and preservation of the environmental benefits of forests. Environmental concerns to protect rainforests for global benefit and to protect the way of life of forest dwelling communities have led to pressures on southern governments to restrict timber exports, to the introduction of timber import restrictions and to other interventions. The impact of these interventions on local people, on economic growth prospects and on the possibilities for improved conservation and management of forest resources is poorly understood.

Annex 2 summarises high priority research needs for addressing the five problem areas outlined above, based on the conclusions and recommendations of the series of Policy Workshops.

\section{Forestry and Agroforestry Policy Research Methodology and Institutional Capacity}

The Workshop participants expressed concerns about weaknesses in both current forestry and agroforestry policy research methodology and in national institutional capacity for policy analysis. A particularly critical constraint is the lack of solid empirical data on which to base meaningful policy analysis. An associated issue was the need for more effective ways of ensuring that the recommendations arising out of policy research are more widely adopted.

A range of options was discussed for overcoming these bottlenecks. Some of the most pressing needs identified in this area include:

- A more interdisciplinary approach to field farm and forest surveys to develop quantitative measures of key variables on tree production, income, use, etc. and to provide benchmarks for research analysis.

- Historical reconstruction of land use change, using archival research, oral history, historical studies in geography, anthropology and farm management, plus review of local legal records to identify changes in ownership and land use conflicts.

- $\quad$ Rigorously designed qualitative studies to understand patterns of consumption, tree use preferences, and control and management.

- Exploring options for permanent monitoring systems to parallel those already widely used for crops and livestock. Examples cited, included national agroforestry surveys under implementation in Burundi, analysis of trees in land use through use of remote sensing techniques (under implementation in Kenya), tree product market surveys (as have been carried out in parts of India), and long term monitoring of agroforestry farming system yields (as implemented by CATIE in Central America).

- Better understanding of the political and institutional constraints to adoption of policy reforms. This reflects the reality that despite the considerable investment that has been directed to policy research in the past and the prodigious lists of recommendations that have been generated for policy reform and institutional change, the political unacceptability of such recommendations has frequently precluded their adoption. Better mechanisms are needed for interaction with political leaders and national government agencies responsible for policy formulation. The role of NGOs in this area is of particular interest.

Institutional approaches to research require closer integration betweenforestry research 
research institutions and specialised, socioeconomic, anthropological, agricultural and energy research agencies.

\section{Part II: The Forestry and Agro- forestry Policy Research Programs of the CGIAR Centres}

\section{(a) Criteria for the Selection of problem areas and research needs that are most appropriate for CGIAR Support}

In developing a CGIAR response to the problem areas and research needs emerging from the Regional Forestry and Agroforestry policy Workshops, priority was given to tackling problem areas and research topics that clearly meet the requirements of the CGIAR's recently broadened mission statement which reads as follows:

"Through international research and related activities, and in partnership with national research systems, to contribute to sustainable improvements in the productivity of agriculture, forestry and fisheries in developing countries in ways that enhance nutrition and well being, especially of low income people”.

That mission statement implies a focus on:

- International research that complements and supports national research efforts.

- Satisfying human needs from agriculture, forestry and fisheries without degrading the environment or the natural resource base.

- The large numbers of poor people living in developing countries.

- The role of technological change in generating new income streams for the poor.

- Other activities aimed at strengthening national research capacities, such as specialised training, institution building and information services.

Secondly, the choice of research topics for CGIAR support was influenced by consideration of the types of strategic research that most likely to be of global and/or regional significance such as the development of technologies or policies for resource management and sustainable land use appropriate for application to a range of agroecological conditions widely distributed around the globe. Thirdly, there has been growing recognition within the CGIAR system over recent years of the desirability of a more intercentre collaborative approach to tackling resource management problems in an ecoregional context, combining socioeconomic, biological and physical research in an integrated way. This approach is a response to the recommendations of a recent overview by the CGIAR's Technical Advisory Committee (TAC) of CGIAR Strategies and Priorities. That review ("A Possible Expansion of the CGIAR" AGR/TAC/IAR/90/24) and further analyses by TAC were concerned with the institutional and research implications of the revised goals of the CGIAR that now include much stronger emphasis, than in the past, on conservation and sustainable management of natural resources including soils, water, forests and fishery resources.

One outcome of that review was a decision taken in 1990 to add an additional five centres to the CGIAR System (including ICRAF and CIFOR). At the same time it was agreed to broaden the mandate of several of the existing centres to include more intensive research on natural resource conservation and management within their own particular regions. Thus, CIAT is now taking a lead role in defining resource conservation and management research needs within selected agroecological zones of the Latin and Central American regions. Similarly, IITA is playing a lead role in the humid tropics of the West Africa region, ICRISAT in the semi arid and arid drylands of South Asia and the Sahelian countries of Africa, IRRI in the humid tropics of South East Asia, and ICARDA in the arid zones of the Middle East. Within the above framework, the CGIAR system is well placed to make a significant contribution to tackling many key aspects of all five problem areas identified in Part I of this report. The three Centres that will be most directly concerned with forestry and agroforestry policy research are CIFOR, ICRAF and IFPRI. In addition to these three Centres, the designated ecoregional Centres all have the potential to take on specific forestry and agroforestry research problems of relevance to their respective ecoregional spheres of operation. So far, the possible contribution of these ecoregional Centres has been most clearly 
defined for CIAT working in the forest hillsides and forest margins of Central America and the Amazon Basin. As CGIAR research in this field evolves, it is likely that other ecoregional Centres will also be able to make a useful contribution.

\section{(b) Emphasis on Forestry and Agro- forestry Policy Research in the Medium Term Plans of CIFOR, ICRAF and IFPRI}

\section{(i) Center for International Forestry Research (CIFOR)}

In broad terms CIFOR will be concentrating its main policy research efforts on tackling underlying causes of tropical deforestation, on improved understanding of policies and incentives to ensure the sustainable management and increased productivity of natural forests and reforestation of degraded lands, on researching systems aimed at valuation and more equitable distribution of benefits and costs of forest goods and services (with a special focus on non-wood forest products), on alternative institutional arrangements for involving local people in forest management, and on policies that will help better to quantify and preserve the environmental and biologicdl benefits of forests, including the preservation of biodiversity and carbon sequestration CIFOR's Policy Research Program will embrace five main areas of activity:

- Policies and Incentives for Sustainable Forest Management.

- Valuation and Equity of Benefits and Costs.

- Adoption of Policy Change.

- Employment and Incomes from Forests and woodlands.

- Future Supplies and Demands for Forest Goods and Services.

(ii) International Centre for Research in Agroforestry (ICRAF)

ICRAF's policy related research will continue the strong emphasis that ICRAF has given over the last 15 years to farm level research aimed at improved understanding of local farmer and community perceptions of the value of on-farm trees and woodlands, particularly from the perspective of the role that trees can play in contributing to agricultural sustainability and to the farmers' welfare. ICRAF is also spearheading a Global "Alternatives to Slash and Burn" (ASB) Project aimed at tackling one of the main contributors to tropical deforestation, i.e. shifting cultivation in situations of increasing population pressure, shortening fallow periods, declining crop yields and ecological degradation. ICRAF's Program 1 defines three main areas of agroforestry policy research. They are:

- Agroecosystem characterization of priority environments and land use systems to identify constraints and opportunities for agroforestry research and to delineate extrapolation domains.

- Development of an understanding of how selected policies constrain or support the adoption of agroforestry technologies and design of adoption mechanism for policy implementation.

- Impact assessment, the objectives of which are to measure ecological, economic and social impacts of key agroforestry technologies on agricultural sustainability, rural poverty, farmers' welfare, environmental preservation and climate change.

\section{(iii) International Food Policy Research Institute (IFPRI)}

IFPRI's main contributions to tackling the problem areas outlined in Part I of this report will be implemented by IFPRI's Environment and Production Technology Division, particularly through two projects that focus on "Forest Margins" and "Fragile Lands". These projects incorporate case studies of institutional arrangements for promoting sustainable resource use; marketing studies focussing particularly on forest and non-forest tree products; methodologies for assessing the interrelationships among soil degradation and farm level resource management decisions (especially forest conversion); participatory community monitoring systems to assess the effect of policies on natural resource management (including forests and trees). Also IFPRI will continue to work on how macroeconomic and structural adjustment policies affect agricultural productivity, equity, trade and the environment 
(areas in which IFPRI's past research experience could be of considerable relevance to the forestry sector). Five main areas of agroforestry and forestry policy related research to be undertaken by IFPRI include:

- Arresting deforestation and resource degradation in the forest margins of the humid tropics.

- Sustainable development in fragile forest lands.

- Property rights and communal action for forest resource management.

- Tree product markets

- Macroeconomic policy, trade and the environment.

\section{(c) The CGIAR'S Planned Response to the Recommendations of the Regional Forest Policy Workshops}

In response to the recommendations of the Regional Forest Policy Workshops, CIFOR hosted a Forest Policy Workshop in Bogor, Indonesia in February 1994. Representatives from four Centres - CIFOR, ICRAF, IFPRI and CIAT - participated in that Workshop. The two main objectives of this Workshop were:

- Selection of problem areas and research needs that fit well 'with the various CGIAR Centre mandates, in execution of which the CGIAR would have some comparative advantage and which, in terms of CGIAR goals are deserving highest priority.

- Possible modes of intercentre collaboration that would exploit the complementary strengths of different Centres.

The main problem areas and research needs discussed were those identified by the Regional Workshop participants as summarised in Part I and Annex 2 of this report. In addition to the two main objectives of the meeting summarised above, the Workshop also briefly discussed:

- Preliminary identification of geographic locations where additional CGIAR field research sites might be located.

- The importance of closest possible collaboration with NARs. These were defined in a broad context to include a range of different local institutions such as national forestry research institutions, universities, specialised policy research institutes, NGOs and government policy researchers and decision makers located in various different ministries.

- The role of the CGIAR Centres in Policy Research Training.

These three latter points (and particularly the role of the NARs), will be a major focus of the follow up discussions that the three individual Centres are now in the process of implementing within the various geographic regions in which they are concentrating their policy related research activities. Because these regional interactions with NARs are still ongoing, and because further time is needed to develop more specific proposals on the CGIAR Centres' possible contribution to policy research training, this report only summarises the conclusions and recommendations of the Bogor Workshop emerging from discussions of the two main objectives of the meeting as defined.

Table 1 summarises the research topics emerging from the Bogor Workshop discussions that were regarded as being of high priority for CGIAR support and that fit well with the research agendas already defined in their Medium Term Plans which cover the period 1994- 1998. These cover 28 of the 40 different research topics identified by the Regional Workshops. Table 1 also indicates the research areas of particular interest to CIFOR, ICRAF and IFPRI.

As noted earlier, CGIAR Centres such as CIAT in Latin and Central America, IITA in West Africa, ICRISAT in the arid zones of South Asia and Africa, and IFPRI's in the humid tropics of South East Asia, will also be playing a significant role in natural resource related research in the ecoregional zones that fall within their geographic mandates. Of these other ecoregional Centres, only CIAT was represented at this Workshop. The contribution of the CGIAR ecoregional Centres to forestry and agroforestry research will also be a focus of the follow up discussions and research activities that CIFOR, ICRAF and IFPRI have already initiated, or which they now plan to undertake within the regions. For that reason no attempt has been made in this report to cover the likely research agendas of these other centres. 
A major thrust of the Workshop discussions focussed on the interdependency and interlinkages between many of the 28 research topics that appear to be most appropriate for CGIAR support, and on how the Centres could most effectively collaborate so as to address these research topics in an integrated way. It is the CGIAR's intention to combine the biological and socioeconomic scientific expertise of various CGIAR Centres to take into account their comparative strengths and complementary research mandates.

The following sections summarise how the three Centres intend to address the five main problem areas that were regarded by the Regional Workshop participants as being of highest priority.

\section{Problem Area 1: Policies to contain inappropriate Tropical Deforestation}

Both the underlying causes of tropical deforestation and possible solutions vary geographically and ecoregionally. The problem embraces closed forests, watersheds and open woodlands. The pervasiveness of this problem and complexity of the wide range of possible policy, institutional reform and technological solutions, requires a concerted and integrated effort by the three Centres, all of which will participate in addressing various facets of the problem.

In the context of tropical deforestation, the CCIAR is strongly committed to contributing to resolution of the concerns expressed at the Rio UNCED conference about the negative impact of deforestation on human welfare, agricultural sustainability and the environment. Those negative effects include the declining availability of fuelwood, fodder, medicinal and other essential forest products and forest derived agricultural inputs (which impact most negatively on the rural poor), permanent loss of germplasm of important agriculture and forest crops, ecological deterioration of fragile upland environments in which deforestation contributes to accelerated soil erosion and disruption of stream flow; and the negative impact of forest burning on global warming.

Notwithstanding these concerns, a recurring theme of the Policy Research Agendas of the Medium Term Plans of all three centres is the desirability of improved economic and environmental analysis of different land use options in tropical forest areas. The CGIAR wants to introduce a less emotive, more balanced and scientifically based dimension into the deforestation debate. It is clear that not all deforestation is inappropriate. Given the inevitability of increasing population pressures on tropical forest lands, the Bogor Workshop participants strongly endorsed the recommendations of the Regional Workshops that more attention should be devoted to distinguishing between situations where conversion from forestry to productive and sustainable agriculture does not imply serious risk of ecological deterioration or loss of biodiversity.

For example, large areas of the miombo savanna woodlands on acid soil of southern Africa have good potential for food production and are situated on relatively flat land where conversion to agriculture does not pose serious risks of erosion or disruption of water catchment yield (see, for example, "Soils Research in Africa: A Long Term Strategy" by Sanchez, Swift, et. al., A Report to the Rockefeller Foundation, January 1991). The implication is that CGIAR research into underlying causes of deforestation should incorporate, at a very early stage, a review of the already available studies and data on tropical deforestation, based on criteria that will bring into sharper focus the difference between productive and nonproductive deforestation.

With reference to the six specific macroeconomic policy research topics that were rated by the Regional Workshops as being of highest priority for containment of deforestation (see Problem Area 1 in Table 1), IFPRI will be collaborating closely with CIFOR in addressing research topic 1.1 which focusses on the influence of macroeconomic and sectoral policies (including structural adjustments) on regional development patterns, rural poverty and prospects for economic growth and trade. These are areas in which IFPRI's experience in tackling similar issues in the agricultural sector can be of particular relevance to forestry.

Within the context of the ASB Project, either IFPRI or ICRAF, or both, will focus on the analysis of factors that influence population migration (research topic 1.2); the influence of agricultural policies on colonisation, conversion from forest to agriculture and the negative effects of slash and burn agriculture on human welfare and the environment (research topic 1.3 ); the influence of highway and rural 
infrastructure programs on forests (research topic 1.5) and intersectoral planning processes that may influence deforestation (research topic 1.6).

CIFOR will be concentrating its research in Problem Area $\mathrm{I}$ on the influence of alternative logging road and extraction policies on population migration into forest lands (research topic 1.2). As an input to the ASB Project, and also in the context of its own research programs aimed at preservation of biodiversity, CIFOR will undertake research aimed at improving the understanding of the potential of buffer zone policies to relieve pressure on biologically unique forests and protected areas, and on incentive policies for sustainable forest management, forest conservation and reforestation (research area 1.6). In these areas CIFOR plans to work collaboratively both with IFPRI and ICRAF. The latter will be addressing the possible contribution of policies designed to accelerate the adoption of improved agroforestry farming systems within the buffer zones that have the potential to relieve pressure on natural forests.

\section{Problem Area 2: Valuation of Forest and Tree Benefits}

The development of improved methods for evaluating the costs and benefits of tree and forest goods and services, assessment of the human and environmental effects of deforestation, estimation of externality benefits and the impact of commercialisation of forest products on different socioeconomic and gender groups, were all rated as research areas of high priority for the CGIAR.

Despite the high priority accorded to this topic by the Regional Workshops, concerns were expressed about the lack of reliable data on which to base scientific analysis of forest benefits. For example, notwithstanding growing recognition of the useful role that non-timber forest products play in contributing to rural people's needs and the desirability of improved methods of evaluation of these products, very little systematic physical research has been carried out on the distribution, availability, growth characteristics and possibilities for sustainable management of such products.

This problem area is important to CIFOR's Policy Research agenda which is based on an underlying hypothesis that one reason why forests are disappearing is because they are consistently undervalued by almost all stakeholders. The reasons are manifold (e.g. market distortions, insecure tenure of farmers or concessionaires, arbitrary timber pricing and allocation policies by governments, etc.). In this context CIFOR will support rcscarch on various aspects of research topics 2.1 and 2.2.

IFPRI's comparalive advantage in this area lies in development of methodological approaches for evaluation of natural resources within the framework of its more broadly based research on natural resource evaluation. From this perspective it is well placed to make a significant contribution to tackling research topic 2.2 which will be testing standardised methodologies for the valuation of nontraditional and non-wood forest products. Working in that area, it will be heavily dependent on close collaborative linkages with CIFOR's biological and policy research activities on the same topic.

CIFOR, IFPRI and ICRAF will collectively be addressing different facets of research topic 2.3, which focusses on evaluation of tree product markets. Emphasis is on products that can be produced from natural closed forests (CIFOR's area of concern), common lands or smallholder farms (the latter being ICRAF's main interest). Research will highlight constraints to development of markets, particularly for non-timber forest products (which is an area of special concern to CIFOR), with special emphasis on market characteristics, common types of market failure and their implications for evaluation of equitable sharing of benefits by local communities and tree growers. In this latter area IFPRI's experience of tackling similar issues as they relate to marketing of agricultural and livestock commodities, should be of considerable relevance to the forestry sector.

Research area 2.4 is an activity of special concern to CIFOR, which in the context of developing methods for complete evaluation of forests, will be concerned with valuation of biodiversity and quantification of externalities. ICRAF is also involved in valuation studies of the biodiversity and environmental benefits of agroforestry systems. This work is intended to lead to identification of policies and mechanisms for ensuring equity in the distribution of total costs and benefits among all 
stakeholders. This could include, for example, compensation to local tree growers for externalities including, at the international level, setting aside of forests for preservation of biodiversity and carbon sequestration. In this latter context, there is a close link within CIFOR to the research it is conducting on the potential of reduced impact harvesting and management technologies to contribute to increased carbon sequestration.

\section{Problem Area 3: Local Participation}

Improved understanding of the factors influencing household level decisions to conserve and manage forests and trees, and of the policy incentives to encourage people's involvement received the highest priority of all research needs reviewed by the Bogor Workshop participants. All three Centres see a need to focus on that topic. There are strong linkages between research in this area and those research topics discussed under both Problem 2, and Problem 3 which is concerned with the role of trees and forests in improving human welfare.

For example, the willingness of local people to participate in the management of a wide range of both timber and non-timber forest products depends firstly on better knowledge of the availability, value and possibilities for sustainable management and marketing of those products (research topics 2.1 and 4.1), and secondly on the introduction of satisfactory tenurial options that provide the necessary incentive for local people's participation (e.g. the need for improved institutional arrangements that will effectively involve local communities in the sustainable management of common property resources). This interdependency of research needs between the various Problem Areas has implications for both research project design and selection of research sites. In practice it should be possible to undertake much of the research proposed under Problems 2, 3 and 4 on the same sites.

CIFOR's focus will be on modelling the variables to which households respond in relation to their perception of the usefulness of forest goods and services, and their willingness to undertake protection and management of closed forests. CIFOR is giving high priority to research on impediments to local management of forests. Recently it conducted a workshop in the Southern Africa region that examined research needs relating to improved prospects for management and conservation of the savanna woodlands of the miombo region.

ICRAF's work in this area will be more concerned with household decision making in relation to adoption of new or improved traditional agroforestry systems. IFPRI's research will be carried out within the framework of IFPRI's more broadly based investigations into how household level decisions affect prospects for effective conservation and management of a wider range of natural resources. A similar pattern of complementarity will be applied to addressing the research needs listed in Items 3.2 and 3.3 of Table 1 which are concerned with the questions of how various forms of land tenure, tree ownership policies and legal constraints influence the possibilities for local people's participation in forest and tree management. An area of special concern in this context is the question of how to devise effective institutional arrangements that will provide incentives for local community involvement in the management of common property resources.

The issues in this area are somewhat different in closed forests and forest margins or agroforestry situations. In the former there is need for a greater emphasis on the question of how centralised control and management of closed forests and the tenurial and legal regulations that are frequently applied in natural forests under government control, may actively inhibit local participation. This is the major thrust of planned CIFOR research. Outside forest margins and in agroforestry situations, there are frequently tree ownership and felling restrictions that discourage the effective management of on-farm trees or common property woodlands, where there may be gender problems that exclude the participation of women in decision making about the use and management of common property or on-farm tree resources. These latter concerns are of particular interest to ICRAF and IFPRI.

Research topic 3.4 is of special relevance to the ongoing attempts by CIFOR to develop and test more standardised and systematic quantification of the impact on human welfare, productivity of forests and the environment of the many small scale experimental attempts that are now being made to introduce alternative institutional options for encouraging local participation. Most of the reporting to date on 
progress in this area has been more anecdotal than scientific. There are strong linkages between this work and that proposed under research topic 3.6 which will address policy reform options for public forest sector agencies. Research topic 3.5 which deals with improved understanding of indigenous forest dwelling people's rights of use and access to forests, is a particularly relevant research issue for the countries of the Amazon Basin where "extractive reserves" have been proposed as one possible option for protecting indigenous people's interests. There are many unanswered questions about the economic viability and long term sustainability of such reserves that CIFOR plans to address. Before embarking on research in this area, it would be useful to carry out a thorough literature review of the many earlier studies of "extractive reserve" experiences and of the concerns that have been raised about their economic viability.

\section{Problem Area 4: The Role of Trees and Forests in Rural Welfare}

This problem area responds firstly to growing recognition that an increasingly high proportion of rural people's needs for essential forest products such as fruits, fuelwood, fodder, building poles and even for more conventional forest products such as timber, is now being produced from agroforestry farming systems, forest fallows and remnant patches of natural forest, open woodlands or from common property grazing lands that are frequently outside the jurisdiction of government forest agencies. It was partly recognition of this fact that triggered the decision taken in 1978 to create ICRAF, which operated as an independent non-CGIAR Centre for some 13 years before it was incorporated into the CGIAR system in 1991.

Within the remaining closed natural forests of the tropics, the objectives of management have evolved from an earlier strong emphasis on production of conventional forest products (which dominated national forest policy and aid agency support programs throughout the 1960s and early 1970s). Today a much broader set of management objectives is reflected in most national forest policies, including increasing emphasis on the role that literally hundreds of forest plants, trees and wildlife species play in meeting subsistence needs and contributing to the livelihoods of indigenous forest dwelling and forest fringe communities.

Another aspect of Problem Area 4 is the concern that is now widely shared by many tropical country governments about the vast areas of former forest, but now degraded lands (such as the imperata grasslands and saline lands of Asia). Reclamation of part of these areas could play a significant role in meeting future food and forest product needs. All three facets of Problem Area 4 fit very closely to the objectives of the CGIAR's Mission Statement which is primarily concerned with the sustainable improvements in the productivity of agriculture, forestry and fisheries in ways that will enhance the nutrition and well being of low income people for subsistence or for industry. All three of the CGIAR Centres have complementary but interrelated roles to play in implementing the research listed under Problem 4 in Table 1 . For example, Item 4.1 which is concerned with improved quantification of the role of trees and forests in contributing to rural welfare and is closely linked to the "valuation" issues discussed in Problem Area 2 above, is already a major thrust of the research agendas of both ICRAF and IFPRI. As CIFOR's research into the valuation, dynamics of consumption and marketing prospects for non-timber forest products gains momentum, there will be obvious benetits from close collaboration between all three Centres in developing common methodologies and defining an operational framework for measuring the impact of adoption of improved agroforestry and forest management systems.

Research topic 4.2 which deals with policy research into traditional and new agroforestry systems and policies that will encourage their wider adoption, is another key component of ICRAF's program which is likely to benefit from the more broadly based research being carried out by IFPRI on policy incentives relating to a wider range of natural resource management issues.

In this context, IFPRI is collaborating closely with CIAT in the Central and Latin American region in researching policy options that could have a positive impact on the management of fragile uplands as part of CIAT's Forest Hillsides and Forest Margins programs. 
Research topic 4.3 involves research both by ICRAF and IFPRI, into how to factor support for agroforestry needs (including gender concerns) into public agency strategies and programs.

Research topic 4.4 which deals with evaluation of policies that could have a beneficial impact on reclamation of degraded lands, is an issue of concern to all three Centres. CIFOR and ICRAF are already collaborating in the development of a research agenda that deals with reclamation of imperata grasslands. Research topic 4.5 is concerned with the potential of agroeconomic zoning, application of satellite monitoring and GIS based analyses to define priority areas for research in the context of reclamation of degraded lands. It reflects concerns that given the enormous geographic extent of degraded land (e.g. more than 16 million hectares of imperata grasslands in Indonesia alone), research on this topic needs a sharp focus on demographic, socioeconomic, marketing and other factors that will ensure that the outputs of research in this area are channeled towards sites and situations where reclamation is likely to be socially acceptable and economically justified.

\section{Problem Area 5: Policy Options for Improving the Intensity and Productivity of Forest Management and the Efficiency of Forest Industries}

The research needs on this topic are primarily within CIFOR's mandate although in some areas (such as the influence of macroeconomic policies, structural adjustment and other policies on the timber trade), IFPRI should also be able to make a substantial input. The latter's ongoing program related to agricultural food production and trade policies has considerable relevance to forestry.

Item 5.1 which focusses on the viability and constraints to improved efficiency of small scale rural forest-based industries and their potential contribution to rural welfare and economic growth, will build on earlier FAO studies of this issue. CIFOR will be active in this area, initially in South Asia and in the Southern African region where as already noted, it recently hosted a workshop on social, economic and institutional reforms of the savanna woodlands of that region.
In this area there will be strong linkages with research by both CIFOR and IFPRI into Tree Product Markets already discussed under Problem Area 2 and into Valuation and Local Participation issues discussed under Problems 2 and 3 above. The desirability of vertical integration between growers and processors of forest products (as a way of ensuring equitable distribution of benefits) implies that CGIAR research in this area will inevitably have to explore the technological and economic implications of growing, processing, transporting and marketing of forest products.

Under research topic 5.3 which is concerned with improved quantification of the costs and benefits of accelerated industrialisation policies on incomes, welfare and forest management, CIFOR research will build upon ongoing research into this topic by many other research and government forest agencies. CIFOR's support will be in the context of the implications of such policies to human welfare and equity. The implications of alternative industrialisation policies for conserving environmental benefits of forests such as biodiversity preservation and carbon sequestration will also be considered.

Research topic 5.4 which addresses the impact of government timber concession license and taxation policies on possibilities for improved rental capture and improved forest management, is another area where research is already being supported by other agencies such as the World Bank. The role that CIFOR might play in this area is still under review, as it is of high priority only in a few countries.

Similarly under research topic 5.5 which will examine improved understanding of the likely impact of environmentally driven concerns to restrict tropical logging on the livelihood of local people, economic growth and forest conservation, CIFOR's precise role has still to be defined. There are obvious potential linkages with other areas of biological research that CIFOR will be implementing which address the need for standardised methodologies for measuring the impact of various industrial logging systems on biodiversity and on carbon sequestration.

\section{(d) Alternative Modes of Intercentre Collaboration}

To tackle globally important environmental problems (such as the negative impact on 
human welfare and the global environment of slash and burn agriculture in tropical forests), some of the five problem areas identified in Part I of this report might most effectively be addressed by establishing an ecoregional network of IARCs, national research institutions and specialised research agencies working collaboratively in preselected sites in each of the three major geographic regions (Asia, Latin America and Africa).

There would be advantages in appointing a "Convening Centre" the function of which would be to orchestrate and ensure the creation of effective coordination mechanisms for such global research programs. This is the model used in setting up the Global ASB Project for which ICRAF is acting as the lead centre. Other major problem areas and strategic research needs of common interest to the three regions might more effectively be tackled by an informal consortium of IARCs, national institutions and specialised agencies independently working on various interrelated aspects of the same problem over a range of mutually agreed sites. For such networks there may be no need for a "Convening Centre" provided that clearly defined arrangements are Put in place for ensuring common methodological approaches for periodic interaction on progress and assessment of emerging results. To illustrate how these alternative approaches might work in practice in relation to CGIAR implemented agroforestry and forestry research programs, the Bogor Workshop discussed two specific problem areas. These were :

- Containment of deforestation in the Rondonia/Acre region of the Brazilian Amazon (which is one of the eight benchmark sites selected for implementation of the Global ASB Project).

- Testing of various alternative institutional approaches to forest management over a range of Asian, African and Latin American region sites. Special emphasis will be given to testing the validity of a hypothesis that in many tropical forest situations, forest resources are likely to be conserved and more productively managed by local communities, "user groups" or other locally devised institutional approaches, rather than by centraiised public forest agencies. (i) Containment of Deforestation in the Brazilian Amazon: The Global "Alternatives to Slash and Burn" Project

The overall goals of the ASB Project are to reduce the rate of deforestation caused by slash and burn agriculture, to rehabilitate degraded lands caused by slash and burn and to improve the well being of slash and burn farmers by providing alternative land use practices. Succinctly stated the project addresses the questions:

"What are the alternative land use systems to slash and burn that reduce deforestation, poverty and global environmental changes such as decreased greenhouse gas emissions and loss of biodiversity, and how can these alternative systems be promoted?"

The following main research activities to achieve this goal have been identified.

- Identifying appropriate technologies and improved production systems that are economically feasible, socially acceptable and environmentally sound alternatives to current systems.

- Assessing the socioeconomic and biophysicai processes leading to deforestation, including decision making patterns of farmers practising slash and burn.

- Quantifying the contribution of slash and burn agriculture and alternative land use practices to global environmental changes.

- Identifying policy options and institutional management issues that facilitate the adoption of the improved systems and also discourage further deforestation.

Phase I of the ASB Project has made considerable progress in addressing the first two of the above objectives. The policy related research dimensions of Phase I have been primarily concerned with characterisation related research at three regional benchmark sites and very much focussed on household level analysis of the various factors that have been triggering expansion of slash and burn agriculture and on technologies and policy incentives that will provide an alternative. Phase I did not include the wider range of policy research topics identified by the Regional 
Workshops and discussed at the Bogor Workshop that will need to be addressed if tropical deforestation is to be contained. As the ASB Project proceeds (particularly in Phase II), more attention will be devoted to addressing the three latter objectives set out above.

In the context of socioeconomic policy research required to address the deforestation problem effectively, the range of planned CGIAR research activities summarised in points 1.1-1.6 under Problem Area 1 of Table 1, were those identified by the participants in the Bogor Workshop as being of highest priority.

Working from the premise that these policy research topics will be included in Phase II of the ASB Project, the Bogor Workshop explored how in practice the planned policy research activities of the three CGIAR Centres would complement each other. The assumption was made that all three Centres will be collaboratively working in one or more of the eight research sites already selected for such work (which is the case in the Rondonia/Acre region of the Brazilian Amazon).

To illustrate how the different Centres intend to collaborate and harmonise their research on a single site, the Workshop participants discussed, in relation to Problem Area 1 ("Policies to Contain Inappropriate Deforestation"), how to use the respective areas of comparative advantage of the three Centres in contributing to future implementation of the ASB Project most effectively.

Whilst all three Centres have a strong interest in researching this issue, their respective research goals and anticipated research outputs will be significantly different. Thus, CIFOR's policy related research in this area will be particularly focussed on policies that will lead to improved possibilities for involvement of local communities in the management of closed forests in buffer zones surrounding high priority biodiversity reserves.

CIFOR will be particularly concerned with such issues as the possible influence of various tenurial, institutional and processing and marketing options on local people's interest in protecting and sustainably managing natural closed forests for a range of subsistence and commercially saleable products. Also their influence on the willingness of timber companies to organise logging operations in a way that would be least damaging to soil and water resources and to young natural regeneration would be considered. CTFOR's planned research on improved understanding of global externality benefits such as preservation of biodiversity and carbon sequestration, and on the justification and institutional possibilities for North-South concessional funding transfers (e.g. by the Global Environmental Facility), clearly has the potential to make a significant contribution to slowing the pace of inappropriate deforestation.

ICRAF's policy related research in the ASB Project will continue to focus on the influence of various tenurial and other incentive policies that will encourage the more rapid adoption of improved agroforestry systems. ICRAF is particularly concerned with such issues as the potential contribution of on-farm trees to increase farm productivity, improved food security, reduced farm risk, generation of rural incomes and protection of soil and water resources. Those research topics are distinctly different from those planned by CIFOR as outlined above (and they require a somewhat different range of socioeconomic and farming systems research expertise). Nevertheless, within the context of the ASB Project, the major objective of both Centres is same, i.e. how can improved forestry and agroforestry policies help to contain inappropriate deforestation? Accelerated adoption of improved agroforestry systems in forest margins and buffer zone forests has obvious potential for reducing encroachment pressures on natural forests.

IFPRI will also play a key, but differently focussed role in this area, concentrating on topics where IFPRI has a comparative advantage such as the influence of macroeconomic, trade and structural adjustment policies on forest land use. Similarly, IFPRI's Household Decision Making research in this area will be a continuation of IFPRI's more broadly based research into the influence of various tenurial, agricultural pricing, marketing and institutional options for conservation and management of a wide range of natural resources, including soil, water and vegetation management in rangelands, upland watersheds and forest margins. The implication is that lessons may emerge from IFPRI's improved understanding of the likely impact of policy reforms on these areas of natural resource management that could be of relevance to stabilising land use management in forestry and agroforestry land use situations such as forest areas being converted to slash and burn agriculture. 
Integration of the findings of these various inter-related research programs into the broader research agenda of the ASB Project will be achieved through the project's existing Global Coordinating Committee which meets regularly at one of the eight benchmark sites selected for that project (which are located in Brazil, Mexico, Peru, Indonesia, Philippines, Thailand, Cameroon and Zambia).

Working within this broad collaborative framework, possibilities for substantial cost savings will likely emerge. For example all three Centres have expressed their intention to work on similar topics such as better understanding of the influence of various land tenure options on people's willingness to sustainably manage forest resources or agroforestry farming systems. Notwithstanding the different aspects of this topic that the three Centres may wish to pursue, there would be obvious advantages in all three Centres combining to engage the services of a single social scientist with specialised land tenure experience to implement tenure related research in an integrated way within the same ASB site.

Such collaboration will be even more cost effective and more likely to achieve a local impact, if it builds on the social science capability of a single national research institution (such as the University of Sao Paulo) which would become the focal point for interaction between the three CGIAR Centres and national research institute on this topic.

\section{(ii) Testing of Alternative Institutional Approaches to Forest Management}

Problem Area 3 listed in Table 1 (Local Participation) is an issue that featured prominently in all the Regional Workshops. To recapitulate, there has been increasing awareness in recent years that centralised management of forest resources by government agencies has, in many situations, Inhibited involvement of local communities in conservation and management of forests and trees. There have been numerous experimental and pilot attempts to test alternative institutional approaches to forest management. However there has been very little systematic research aimed at quantifying the impact of these experiments on the welfare of local communities, on forest productivity or on the environment.
The Bogor Workshop gave very high priority to more concerted research efforts in this area. Out of the range of possible research needs listed in Annex 2 that emerged from the Regional Workshops, it concluded that the six topics listed under points 3.1-3.6 of Table 1 are those that should be strongly supported by the CGIAR. In summary the main research needs in this area include:

- Improved understanding of factors influencing household level decisions to conserve and manage forests and trees, and of policy incentives to encourage their involvement.

- How various forms of land and tree ownership policies can influence the prospects for improved welfare of forest dwelling people.

- Analysis of the legal and institutional constraints to local participation, and policies to address them.

- Standardised methodologies for evaluating and monitoring alternative institutional approaches to forest management in terms of their impact on human welfare, the productivity of forest rcsources and the environment.

- Improved understanding of the rights of use and access of indigenous people dwelling in the forest, and policies to preserve those rights.

- Policy options for reform of public sector forest agencies.

In contrast to the mode of intercentre collaboration described above for the ASB Project (where several IARCs and national institutions will all be working within the same ecoregional site), the Workshop concluded that research on Local Participation issues such as those identified above might be more effectively implemented by a more diffuse networking approach.

Part of the rationale for this alternative mode of operation is the desirability of covering quite a wide range of experimental approaches that are already ongoing in many different sites and agroecological zones, some of which are not likely to fall within the geographic spheres of influence and interest of the CGIAR ecoregional Centrcs (for example the Latin American "Cone" region countries). 
Secondly, the potential national collaborating partners in this work also cover a wide range of situations. Given the limited resources of the CGIAR system and the capability of some of the stronger NARs and specialised policy research institutions to make a significant contribution to research in this field, the need to concentrate the activities of a group of IARCs in the same ecoregional site is less compelling.

The Workshop therefore concluded that the alternative of an informal consortium of IARCs, national institutions and specialised policy research institutes, independently working on inter-related aspects of this problem over a fairly wide range of mutually agreed sites, would be more appropriate.

Under this alternative mode of operation there may be no need for a "Convening Centre" provided that at the outset of such a program, there has been a collective effort firstly to establish common research methodologies; secondly, to ensure coordination in selection of collaborating NARs and specialised research institutions; thirdly, to arrange regular interaction in reviewing emerging results and progress (much of which can now be assured at relatively low cost by making effective use of electronic networking); fourthly, to possess clear mutual understanding from the outset on the likely outputs and potentially different target beneficiaries of such research.

To illustrate how such a network might operate in practice, the planned activities of CIFOR, ICRAF and IFPRI in this area were discussed. CIFOR for example recently financed a major workshop in India devoted to examining various experimental approaches to devolution of responsibility for management of degraded public forest resources to local communities in 15 Indian States. CIFOR researchers will collaborate with researchers in existing national policy research institutions (such as India's Xavier Institute), experts from various local Indian NGOs, the Ford Foundation, and with experts of the various State Forest Departments, in implementing this research program.

As a parallel activity, ICRAF, working in the East and Southern African highlands, has already established strong linkages with many national agricultural and forestry institutions, universities and overseas specialised research agencies in the course of reviewing alternative institutional approaches for more effective local community and farmer involvement in agroforestry systems. ICRAF has on its own staff considerable socioeconomic expertise that it can bring to bear on this topic.

IFPRI has an ongoing major program devoted to Property Rights and Communal Action for Forest Resource Management. It scheduled an international workshop in 1994 on "Policies to Support Local Organisations in Natural Resources Management". This workshop laid out a conceptual framework and methodologies for comparative research in this area. Both CIFOR and ICRAF participated in that workshop. A major focus of IFPRI's research will be on management of local tree resources, including private agroforestry practices which require group coordination or co-management of forests by local organisations.

IFPRI's main research on this topic will be conducted in Central and Latin America as an integral component of IFPRI's collaborative research with CIAT on Forest Hillsides and ICRAF on Forest Margins.

In terms of the planned outputs of research by the three Centres, the target beneficiaries (which will include public forest and land use management agencies), will be different. CIFOR's research, for example on the possibilities for devolution of responsibility for management of public forest lands to local communities, individuals or to private sector companies, will be primarily targeted to government forestry and environmental agencies.

The output of ICRAF's parallel work on policies for accelerated adoption by local communities of improved agroforestry systems in the East and Southern African bimodal highlands, will be primarily targeted at small farmers, government agriculture and rural development institutions in that region. These research results are also likely to be of particular interest to the many local NGOs who are involved in supporting various agroforestry programs.

IFPRI's joint work with CIAT and ICRAF in the Forest Hillsides and Forest Margins of Central America and the Amazon Basin of Latin America, would similarly be targeted at smaller farmers, relevant government decision makers and NGOs in that region.

Notwithstanding the differing facets of this research topic and different target beneficiaries, mutually reinforcing and cross cutting policy 
recommendations are likely to emerge from these parallel efforts that on conclusion of this research will justify a consolidated synthesis by the various national institutions and CGIAR Centres who will have been supporting this work.

\section{(e) Phasing of the CGIAR Centres' Forestry and Agroforestry Policy Research Activities}

The Bogor Workshop discussions were primarily concerned with the substance of a desirable CGIAR research agenda and with the issue of how to ensure effective intercentre collaboration. The program of possible research activities outlined above is based on unconstrained resources which would ensure that the three main Centres under discussion are allocated the resources requested in their Medium Term Plans. The current financial climate in which the CGIAR is operating may require hard decisions to be made about prioritisation and phasing of their forestry and agroforestry policy research activities. 


\section{Annex 1. Priorities for Forestry and Agroforestry Policy Research}

Box 1. Priorities for policy research on population distribution and growth, deforestation, and land use in wet tropical forest zones.

Research should be geared primarily toward reducing migration to agricultural frontiers and toward speeding the transition to more sustainable forms of land use. The following research areas should have high priority.

- research on macroeconomic processes that lead to migration from source areas to environmentally fragile lands; relationship of structural adjustment lending to migration;

- research on institutional reforms needed to strengthen tenure of individuals or of groups to trees and land; the devolution of responsibility for natural resources from government to others; the structure of tenurial arrangements; improvements in public-sector natural resource management; coordination between agencies;

- research on the role of infrastructure and its relationship to deforestation, on logging roads and the rate of migration to frontier areas, and on effects of market access on returns to land use;

- studies on the potential for sustainable land-use technologies to improve returns to land users;

- research on subsidies and pricing policies to understand how to reduce incentives for land clearance and to encourage the adoption of sustainable land uses;

- research on means for stabilizing the distribution and growth of rural populations through off-farm employment and income generation opportunities;

- studies on land-use potential and its relationship to population demographics and biological conservation priorities;

- research into methods for improving the valuation of environmental services provided by forests and trees such as soil erosion prevention, catchment protection, biodiversity, and so on; and

- research on the impact of forest and agricultural-sector policies on deforestation, particularly on policies regarding the development of buffer zones, licenses and concessions, and the relationship between plantation forestry, biological conservation and deforestation.

Box 2. Priorities for policy research on the reclamation and utilization of degraded forest lands and drylands. These areas are located primarily in the arid, semi-arid, and seasonally dry tropics, and in the subtropical semi-arid ecological region of West Asia and North Africa.

Studies of improvement of land-use to increase rural welfare should be undertaken to reflect the range of social and economic conditions that are often a function of ecological potential in dryland areas, These include

- research on optimal land-use strategies, and the policies necessary to encourage the adoption of these strategies, in dryland areas; problems of reconciling local, regional, national and international points of view;

- reviews of policies affecting trees and tree planting that encourage the rationalization of national policies and traditional practices;

- studies of tenure and customary rights to trees to identify how tenure and usufruct act as incentives or barriers to tree management; and

- research on the improvement of markets for tree products from dryland areas to improve market access and returns to forest products. 
Box 3. Priorities for policy research on intensive, sustainable land use in upland watershed areas and woodland preservation.

Research in upland watershed areas should be designed to evaluate how the quality of life of people iving in these areas can be improved, and how environmental conditions in upland areas can be maintained in a way that benefits populations both upstream and downstream. Research should include

- the development of better information about externalities related to upland watershed management, particularly identification of incentives to protect, plant, maintain trees and forest cover; the measurement of social, economic, and ecological interactions between upland and lowland communities and land uses; and how production processes in these respective areas can be stabilized;

- the development of better forest and tree management through understanding of why farmers plant what they do when they do, more creative management systems, tenure and traditional management strategies, and economically viable management systems for extensive commercial forestry that do not compromise the protective functions of forest ecosystems; and

- research into problems of infrastructure, institutions, and marketing, to identify ways to develop more effective market opportunities and new markets; research on how roads and transportatior affect development and migration into upland watershed areas, and how local, regional, and national institutions could best work together to manage and protect forest, tree and land resources.

Box 4. Priorities for policy research on the role of trees in rural income and subsistence security.

Proposed research priorities in this area focused primarily on the relationship of trees and forests to household income and subsistence security.

- research on patterns of demand and use of tree products and services in rural areas;

- studies of markets, marketing, and pricing of tree products from rural households, with a particular view toward more orderly development of tree product markets;

- comparative analysis of alternative forestry and agroforestry systems in the stabilization of existing and new land-use systems, particularly to investigate the evolution of these systems in response to increasing demographic pressures;

- research into aspects of land and tree tenure and control to clarify the relationship between changing land tenure relationship and tree rights;

- studies of common property management of tree resources by individuals, communities, and the state to identify where macro policies conflict with communal management objectives, to determine how these management strategies are affected over time, and to determine how greater local responsibility can be placed over local resources; and

- research about institutional support and services, such as the role of extension, research, and education linkages, and the role of credit and subsidies. 
Box 5. Priorities for policy research on intersectoral policy issues.

Research in this area is needed to assess the effects on forests and on trees on farms and in rural areas, of policies in other sectors to evaluate how policy measures can reduce negative intersectoral effects and enhance positive intersectoral effects.

research on macroeconomic policies affecting forests, such as structural adjustment programs, economic liberalization programs, agricultural and fiscal policies, and industrial development;

- microlevel research on agriculture and forest interactions, particularly to explore the relationship of policies to deforestation, and to identify how negative intersectoral effects can be reduced by stabilizing populations on the extensive margin through practices that increase household income; research on institutional implications of intersectoral linkages, such as the impact of restructuring institutional responsibilities to increase collaboration and coordination between institutions; 


\section{Annex 2. CGIAR Sponsored Forest Policy Workshops - Synthesis of Main Problem Areas and Research Needs}

\section{Problem Area 1}

\section{The Negative Effects of Tropical Deforestation and Options or its Containment}

Throughout the 1980s there was growing awareness and concern about the negative impact of tropical deforestation on human welfare and on both local and global environments. FAO's earlier 1980 Forest Resource Assessment, which had estimated deforestation at something on the order of 11 million hectares a year, was revised upwards in 1990 to a figure of 17 million hectares.

The underlying causes of deforestation are complex. They include for example inappropriate macroeconomics, land use, agricultural subsidy and timber taxation policies, excessively centralised control and management of forest resources, migration of rural landless people into forest areas in search of agricultural land, political pressures to open up virgin forests in order to generate revenues for economic development or to consolidate national political boundaries, the weakncss of government forest administrations, fairly widespread corruption in the allocation of timber licenses and other factors. In addressing this issue a primary thrust of the CGIAR's response should focus on:

\section{"Research directed towards improving the welfare of people who have long resided in or recently migrated into tropical forests or forest margins, and towards improving the productivity of encroached forest lands."}

This approach is consistent with the mandate of the CGIAR which calls for a research agenda that will give high priority to sustainable improvements in the productivity of agriculture, forests and fisheries in ways that will enhance the nutrition and well being of low income people.

Agroecological zoning, population migration, and GIS-based information research could lead to sharper definition of the numbers and geographic locations of various socioeconomic and cultural groups of forest dwelling communities. One objective of such research would be to provide a basis for more accurate targeting of research effort. A second would be clearer definition of research objectives and anticipated impact. Some of the possible areas for further analysis and research are likely to include:

1. Improved understanding of how household level perceptions of the usefulness of forests and trees are likely to influence their willingness to protect and manage forest resources.

2. Improved understanding of the degree of dependence of forest dwellers and migrants on both traditional and non traditional forest products for meeting subsistence needs for income generation, and on prospects for their marketing and processing.

3. Research into improved understanding of the rights of indigenous forest dwelling people, and of policies that are likely to be most effective in preserving those rights.

4. How various forms of land tenure and tree ownership policies can influence the prospects for improved welfare of forest dwelling people and for more effective conservation and management of forest resources.

5. Improved understanding of the potential of forest buffer zone policies to relieve pressure on biologically unique forest reserves and protected areas, and of policies that are likely to be most effective in involving local people in their protection and management.

A second major thrust of planned CGIAR work on the tropical deforestation issue will focus on:

\section{"Research aimed at improved understanding of the underlying external causes of deforestation and of policies that will help to contain it."}

There is now widespread recognition that many of the underlying causes of deforestation arise from outside the forestry sector and that research needs to address how more effective linkages between 
forestry and other sectors can be achieved. However, many of the internationally supported campaigns and action programs that have been developed over the last decade to contain tropical deforestation (including the Tropical Forestry Action Program) have failed to address these external causes.

High priority research needs include:

1. Analysis of factors that influence population migration at source and monitoring of the dynamics of population migration patterns.

2. The influence of government and international macroeconomic policies (including structural adjustments) on regional development patterns, rural poverty, economic growth prospects, trade, and the rate of urbanisation.

3. Research into the impact of land tenure policies on population migration and on the potential of land reform to reduce migratory pressures.

4. The influence of major highway and railway construction programs on forest resources and the possibility of influencing those national transportation policies in a way that would divert such infrastructure projects away from forest areas inhabited bv indigenous forest dwellers and from high priority biodiversity reserves.

5. Ways and means of influencing agricultural policies to discourage colonisation and commercial agricultural schemes in unique forest lands where negative impacts on forest people are likely, or in biologically important forest reserves.

6. Policy dialogue with government, industry and energy agencies based on research into the potentially negative effects of large scale mining, other major industrial and/or dam developments on forest resources and on local people's welfare.

7. Research into timber industry policies and harvesting methods that open up logging roads into forest lands and provide easy access to forest migrants. Improved understanding of the influence of low impact harvesting technologies on forest access, improved prospects for forest regeneration and reduced risk of forest encroachment.

\section{Problem Area 2}

\section{Undervaluation of Forest Benefits}

The negative effects of undervaluation of forest resources recurred as a major theme of common concern in all regions and to most of the national forest policy leaders participating in the Workshop series. It is now widely recognized that most earlier studies of forest values over-emphasised timber and traditional forest product benefits. As appreciation of the environmental importance of forests evolved, more attention is now being given to quantifying externality benefits and to developing modified approaches to pricing of forest products, goods and environmental services. Research that could help address this problem include:

1. Improved methods of data collection for evaluating the costs and benefits of forest goods and services, including data on the human and environmental effects of deforestation, the impact of commercialisation of forest products, different socioeconomic and gender groups; improved data on the quantified externality benefits of forests and trees (e.g. their role in containment of soil erosion and regulation of water supplies); and in a global environmental context, data on the potential effects of low impact harvesting technologies and more careful forest management on carbon emissions and the carbon sequestration value of forests.

2. Testing standardised methodologies for the valuation of non-timber forest products and for monitoring the dynamics of demand and supply, and prospects for their domestication and commercialisation.

3. Formulation of multiple-end use forest policies that broaden the range of harvested and managed products and ensure increased and sustainable access by local people to these products. Valuation studies that guarantee local communities an equitable share in the benefits to be derived from more broadly based and intensified forest management. 
4. Improved and standardised methodologies for biodiversity assessment valuation and monitoring of the impact of different protection and forest management approaches including use of remote sensing and indicator species techniques.

5. Policies that will encourage the accelerated adoption of forest harvesting, regeneration and management techniques that will be most beneficial in reducing carbon emissions from forest burning and increased carbon sequestration.

6. Policies that will provide justification and improved mechanisms for North-South concessional transfers to provide incentives for the setting aside of tropical forests in the interest of protecting the global environment.

7. Policies that will help to improve the way in which current national accounting systems quantify forest benefits. Special emphasis is needed on the possibilities for factoring in the economic and social costs of forest depletion and modifying forest product pricing policies so that they reflect more accurately the ecological benefit to national economies of forest protection and open up new mechanisms for improved economic rental capture.

\section{Problem Area 3}

Institutional Reforms aimed at Ensuring greater Local Participation in the policy Dialogue and in the Conservation and Management of Forest Resources

Centralised management of forest resources has been a feature of many developed and developing countries' forest policies over the last century. Earlier theories about the need for government appointed and managed forest agencies to act as custodians of natural resources on behalf of local people have been seriously questioned. They have clearly failed to contain tropical deforestation. Nor have they ensured local communities an equitable share of forest derived benefits.

Recently there have been many experimental attempts to devolve responsibility for management of formerly government owned forest lands to local communities. NGOs have been particularly active in this area. However monitoring of these pilot experiences has been weak. Most of the dialogue on decentralised management is of an anecdotal nature. There has been very little systematic quantification of the impact of communal management on local people's incomes, the status of the forests after local management has been introduced and the environmental impact of these decentralised approaches.

Part of the continued reluctance of many government forest agencies to proceed further with devolution of forest management to local communities, farmers and/or private industrial companies, stems from the lack of hard evidence that these decentralised management schemes can be safely introduced without serious risk of accelerated forest destruction and environmental damage. Systematic research of these issues could help to clarify the risks involved and develop guidelines for successful devolution of forest management. Priority research topics include:

1. Improved understanding of factors influencing household level decisions on people's willingness to conserve and manage forests and trees, and of policy incentives to encourage their involvement.

2. Analysis of the tenurial, legal and institutional constraints to local involvement, and of policy reforms that could help remove them.

3. Standardised methodologies for evaluating and monitoring the effectiveness of alternative institutional approaches to forest management in terms of their impact on human welfare, the productivity of forest resources and environmental protection.

4. Policy options for reform of public sector forest agencies with special reference to improve mechanisms for ensuring local involvement in policy dialogue and forest management, and for developing stronger intergovernmental agency natural resource planning and environmental protection capability.

5. Historical analyses of how previous centralised forest management policies have impacted on prospects for local involvement. These analyses need to focus on both the negative and positive 
aspects of past reservation policies. They could include case studies where reasonable sharing of forest benefits between local people and government forest agencies have been successfully achieved.

\section{Problem Area 4}

\section{Policy Research into the Role of Trees in Rural Welfare}

This problem embraced improved understanding of policies that aim to increase the productivity of agroforestry systems as well as the role of trees in reclamation of degraded lands. As natural forests throughout the developing world are being depleted, local populations have increasingly turned to remnant patches of open woodlands, forest fallows and agroforestry systems for supplying their essential forest product needs and for sustaining agricultural productivity.

This evolution of supply sources of tree products from natural forests to products that are harvested from remnant woodlands, domesticated on-farm trees or community woodlots has raised many new policy challenges.

However because the interactions between crops, trees and livestock are not well understood, and because government forest institutions have been heavily involved in protection and management of closed natural forests, government agroforestry incentive policies and support services have frequently been ineffective and wasteful of resources. Priority research needs in this area include:

1. Improved understanding and quantification of the contribution of on-farm trees and remnant woodlands to nutrition, food security, agricultural sustainability, rural income generation, reduction of risk in farming systems and protection of soil and water resources.

2. Policy research into traditional agroforestry systems and into policies that would stimulate their wider adoption and improved productivity.

3. Tenurial, legal and institutional constraints to adoption of agroforestry systems and of policy options for their removal.

4. Household level and in particular gender influenced decisions about the usefulness of on-farm trees, and policy options for ensuring that these are taken into account in the formulation of public agency support policies.

5. Policies aimed at restructuring forestry extension services and their closer integration with agriculture, energy and other rural extension assistance programs.

6. Agroeconomic zoning studies aimed at definition of those areas scheduled for reclamation by afforestation to ensure that they do not impact negatively on the rural poor and landless and that there are reasonable marketing prospects for programs that are likely to produce large volumes of commercially useful forest products.

7. Evaluation of the trade-offs between forest-based and alternative agricultural or engineering solutions to degraded land reclamation.

\section{Problem Area 5}

\section{Policy Options for Improving the Efficiency and Profitability of Forest Industries and the Intensity and Productivity of Forest Management}

Concerns about these problems emanated particularly from those countries abundant with timber that depend to a high degree on forest product exports for generating development revenues and local employment. They are also relevant to countries such as Chile, Brazil, Kenya, Zimbabwe, China and India that have developed significant large scale plantation-based forest industries. Research priorities included:

1. Effect of macroeconomic policies onthetimber trade including governmentexport policies,and the impact of structural adjustmentsandexchange rates. 
2. Marketing prospects for traditional forest products.

3. Improved understanding of the impact of tariff barriers and other trade restrictions on the tropical timber industry and on forest management.

4. Scope and justification for subsidies for industrial forest management and plantation forestry.

5. Improved understanding of the likely impact of environmentally driven proposals for restrictions on tropical logging and the timber trade (for example of ecolabelling mechanisms) on the livelihood of local people, economic growth and forest conservation and management.

6. In those situations where environmental restrictions relating to reduction of logging in the interest of global benefits prevail, improved understanding of North-South concessional funding transfer mechanisms.

7. Increased emphasis on research into the viability of and constraints to improved efficiency of small scale forest-based industries, and into their potential contribution to rural welfare and economic growth.

8. Improved quantification of the costs and benefits of accelerated industrialisation policies including increased domestic processing versus log exports.

9. Impact of government timber concession license and taxation policies on the prospects for improved rental capture and for more intensive forest management.

10. Improved administrative policies and mechanisms for monitoring the performance of private sector timber companies. 